\title{
Critical Review of the Parameters Affecting the Effectiveness of Moisture Absorption Treatments Used for Natural Composites
}

\author{
Ahmad Y. Al-Maharma ${ }^{1, *(\mathbb{C})}$ and Naser Al-Huniti ${ }^{2}[\mathbb{D}$ \\ 1 Mechanical Engineering Department, Ozyegin University, 34794 Istanbul, Turkey \\ 2 Mechanical Engineering Department, the University of Jordan, Amman 11942, Jordan; alhuniti@ju.edu.jo \\ * Correspondence: eng.ahmad2020@yahoo.com; Tel.: +962-78-995-8266
}

Received: 20 February 2019; Accepted: 14 March 2019; Published: 18 March 2019

\begin{abstract}
Natural composites can be fabricated through reinforcing either synthetic or bio-based polymers with hydrophilic natural fibers. Ultimate moisture absorption resistance at the fiber-matrix interface can be achieved when hydrophilic natural fibers are used to reinforce biopolymers due to the high degree of compatibility between them. However, the cost of biopolymers is several times higher than that of their synthetic counterparts, which hinders their dissemination in various industries. In order to produce economically feasible natural composites, synthetic resins are frequently reinforced with hydrophilic fibers, which increases the incompatibility issues such as the creation of voids and delamination at fiber-matrix interfaces. Therefore, applying chemical and / or physical treatments to eliminate the aforementioned drawbacks is of primary importance. However, it is demonstrated through this review study that these treatments do not guarantee a sufficient improvement of the moisture absorption properties of natural composites, and the moisture treatments should be applied under the consideration of the following parameters: (i) type of hosting matrix; (ii) type of natural fiber; (iii) loading of natural fiber; (iv) the hybridization of natural fibers with mineral/synthetic counterparts; (v) implantation of nanofillers. Complete discussion about each of these parameters is developed through this study.
\end{abstract}

Keywords: moisture treatments; interfacial adhesion; diffusivity; hydrophilicity; hydrophobicity

\section{Introduction}

The natural fiber-based composites have numerous implementations in different industries since they are good acoustic absorbers and thermal insulators. Furthermore, they can be used as indoor humidity regulators for building through using coatings and layers of natural composites in interior walls' structure [1,2]. Natural fiber-based composites have the potential to be implemented in civil engineering applications such as manufacturing materials for the construction of buildings when the durability and structural performance are considered. Appropriate treatments to improve the durability performance of natural composites will make them in general more competitive to synthetic fiber-based composites [3-5]. The natural fiber-based composites are the most widely used as poroelastic materials in the automotive industry sector. In addition to their higher specific mechanical properties, natural composites can effectively reduce the level of acoustic noise inside the vehicle cabin, similar to synthetic polyurethane foam and commercial rock wool fibers [6-8]. The broad field of application of natural composites can be attributed to the properties of natural fibers, which are characterized by low weight, affordable cost, easy processing, flexibility, biodegradability, and environmentally friendly fibers. The properties of natural composites depend mainly on the characteristics of the reinforcing fiber and the adhesion between the matrix and the fiber [9-11]. There 
are a number of drawbacks that should be resolved in order to disseminate the implementation of natural composites in various industries, such as inadequate adhesion between the hydrophobic hosting matrix and raw fibers, low wettability by non-polar plastics, and high level of water uptake [12-14]. The natural fiber is composed of cellulose, hemicellulose, lignin, pectin, wax, water-soluble substances, and fat. Cellulose is regarded as the main framework element of the fiber structure. It imparts stiffness, strength, and structural stability to the fiber. However, cellulose and hemicellulose are the major constituents of natural fiber that absorb the highest amount of moisture. Lignin provides effective shielding for hemicellulose/cellulose against harsh environmental circumstances such as humidity and temperature [15-17].

The absorption behavior of moisture can be described according to two main models: (i) pseudo-Fickian behavior, where the weight gains of water didn't reach equilibrium after take-off; and (ii) linear Fickian behavior, where the weight gains of water gradually achieved equilibrium after quick initial take-off. The higher moisture absorption facilitates the microbial attack, leading to a process called biodegradation. The transport of moisture inside the natural composites can be facilitated through different mechanisms such as the diffusion of water inside the microgaps among the polymer chains. The water absorbed in the natural composites is classified into bound and free water. The bound water are dispersed molecules of water that are bounded to the polar groups of the polymers, while the free molecules of water have the capability to transport independently through cracks and voids. When the natural composites are exposed to moisture, the molecules of water diffuse into the composite and attach onto hydrophilic groups of natural fibers, forming an intermolecular bonding of hydrogen with the fibers that mitigates the interfacial adhesion at the fiber/matrix interface. The degradation of natural composite's properties take place when the swelling of cellulosic fibers create stress at the interfacial regions, leading to the mechanism of micro-cracking in the matrix close to the swollen fibers, which emphasizes transport and capillarity through micro-cracks. With the excessive absorption of water, the bound water increases while the free water decreases. Water-soluble materials begin to leach from fiber, and finally lead to ultimate debonding between the matrix and fiber. The aforementioned diffusion mechanism of water molecules into the natural composite structure is illustrated in Figure 1 [18-25].

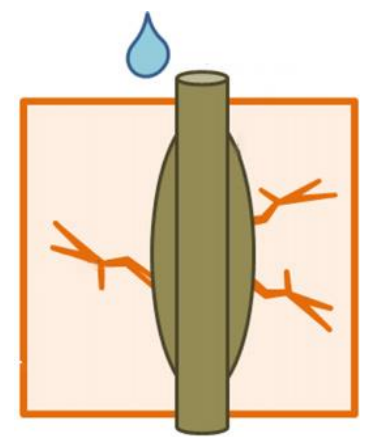

(a)

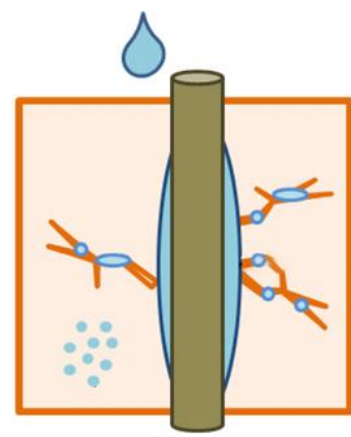

(b)

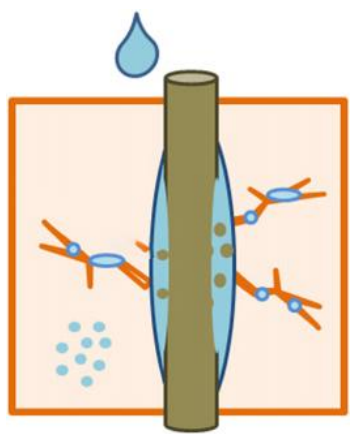

(c)

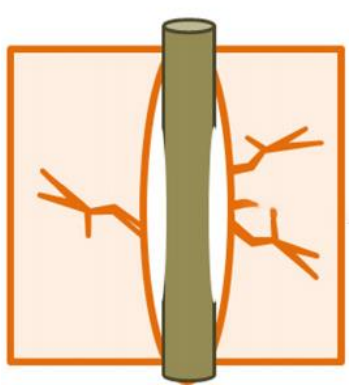

(d)

Figure 1. The degradation of interfacial adhesion due to moisture absorption: (a) development of micro-cracks due to expansion of swollen fiber, (b) water molecules diffused in the bulk matrix flow along the fiber-matrix interface, (c) water-soluble components leach from fiber, (d) ultimate matrix-fiber debonding takes place. Reproduced with permission from [18].

The moisture absorption causes all three dimensions of the laminated composite to increase. Nevertheless, the increase of the composite thickness is very large relative to the increase in width and length. The natural fibers are influenced by water uptake in two directions: (i) swelling of the fiber itself; and (ii) changes in the fiber's density through the weight of absorbed moisture. The water uptake of natural composite is attributed to the polar and hydroxyl groups found at natural fibers. The hydrolysis (chain segmentation of polymer) and swelling emerging from moisture absorption 
induce debonding between matrix and fibers, delamination of the laminated composite, and physical damage to the polymeric matrix, which increase the mechanical and thermal degradation of natural composites' properties [26-30]. Nevertheless, the minor swelling of natural fibers has a positive effect on the mechanical properties of natural composites, since this emphasizes the mechanical interlocking between the matrix and fiber [31]. The water uptake is responsible for increasing the mobility of the side groups and molecular chains, which leads to the reversible plasticization of the polymer matrix [32-35]. The matrix plasticization increases the fracture toughness, while it also reduces the strength, stiffness, fatigue durability, and natural frequencies of the natural composite [36-45]. When the sisal fiber-reinforced polypropylene (PP) composite is immersed in hot water at $90^{\circ} \mathrm{C}$, the tensile strength and modulus are reduced with the increasing immersion time in the water, while the impact strength increases initially with the immersion time. The variety in behaviors between impact and tensile properties can be explained through the swelling effect of the reinforcing fiber and plasticization of the interface between the fiber and the matrix [46]. The diffusion of water molecules into some types of polymer films could substantially change the intermolecular interaction, which significantly contributes to increasing the thermal conductivity, and as a result reduces the thermal insulation properties of natural composites [30].

The water uptake absorption behavior of natural composites is largely affected by many factors such as the chemical and physical treatments of natural fibers, fiber loading, fiber distribution, fiber size and shape, linear mass density of natural yarns, permeability of the fiber, crystallinity of hosting resin, hydrophilicity of each composite's constitute, void content especially at the fiber-matrix interface, duration of exposure to humid environment, fabrication method, conditioning medium circumstances, including temperature, and $\mathrm{RH}$. The surface treatments of natural fibers reduce the hydrophilic nature of natural fibers and introduce significant changes to the surface morphology. The architecture of the fabric has a significant impact on the amount of moisture absorbed by the natural yarns. For example, the twill weave fabrics have optimum mechanical performance even after absorption of moisture. For certain yarn architecture, a lower linear mass density of reinforcing natural yarns provides the composite with greater resistance toward moisture, while retaining at the same time optimum mechanical properties during the moisture exposure period [47-54]. The moisture absorption of natural composites is influenced by the fiber arrangement within the structure of the composite. For example, the non-woven form of the hemp fiber-reinforced polylactic acid (PLA) composite absorbs a higher amount of moisture relative to the aligned fiber composite structure. This can be attributed to the increased porosity resulting from the increased complexity of the matrix flow path during the fabrication process [55]. The surface hydrophobicity of the natural fibers can be enhanced through the application of appropriate chemical treatments, additives, nanocoatings, and bio-based coatings [56-59]. If the coating is appropriately applied and the material characteristics of the coating are carefully chosen, the diffusion of water molecules can be reduced by $50 \%$. Generally, coatings are only effective in offering short to medium-term protection against moisture $[60,61]$. Natural composites with a higher content of voids absorb a higher amount of moisture relative to the ones without voids [62]. Managing the manufacturing environment of natural composites such as maintaining it under vacuum and low humidity is fundamental to reduce the void content that could be created during the manufacturing process. Drying of natural fibers is usually needed to eliminate excessive moisture content. The moisture absorption is directly correlated with the type of natural fiber. For example, flax and hemp fibers have a lower capability to absorb moisture during the manufacturing process of composite relative to ramie and cotton fibers [63]. The hybridization of natural fibers with other synthetic or natural fibers characterized by low moisture absorption tendency is considered an effective technique to reduce the moisture absorption of natural composites [64]. The ambient RH has a direct effect on the moisture content of the composite as well as the average at which it accumulates $[65,66]$. Additionally, it is demonstrated that the increasing temperatures increase the equilibrium moisture absorption and rate of water diffusion due to the activation of the diffusion process [67-69]. However, it was reported in the literature that in some cases, the diffusion coefficient 
increases with decreasing temperatures, since the water molecules bind to the fiber surface through the amorphous waxy materials, which facilitates the water sorption [70].

There is an urgent need to consider both the material durability under different weathering conditions (temperature, rain, air, solar radiation, and oxygen) and life cycle effect during the composite design stage [71-73]. The water uptake and swelling behavior of natural fiber-based composites should be studied thoroughly in order to evaluate the consequent impacts on the performance of composite parts. The swelling coefficient can be calculated through the following equation:

$$
T \%=\left(\frac{T_{2}-T_{1}}{T_{2}}\right) \times 100 \%,
$$

where $T_{1}$ and $T_{2}$ are the initial and final thicknesses of the composite, respectively, while the water uptake can be calculated through the following relation:

$$
W \%=\frac{W_{2}-W_{1}}{W_{1}} \times 100 \%,
$$

where $W_{1}$ and $W_{2}$ are the initial and final weights after immersion [74,75]. The moisture absorption behavior can be described through: (i) diffusivity or the coefficient of diffusion, which characterizes the transport rate of water molecules inside the composite, and controls the duration required to reach the equilibrium moisture state; (ii) the moisture content at equilibrium condition, which describes the composite affinity for water; and (iii) the duration of transient, which is directly influenced by the thickness of the composite [76,77]. To the best of our knowledge, none of the reviewed studies in this review investigate the major parameters that control the efficiency of chemical and physical treatments on improving the moisture absorption properties of natural composites. The combining effect of these parameters along with applying chemical and/or physical treatments could increase or decrease the efficiency of the treatment used. Therefore, this study provides a significant contribution to the existing literature through summarizing the factors that affect the moisture absorption treatments used for the most common natural fiber-based composites which are illustrated in Figure 2 and discussed subsequently in the forthcoming sections of this study.

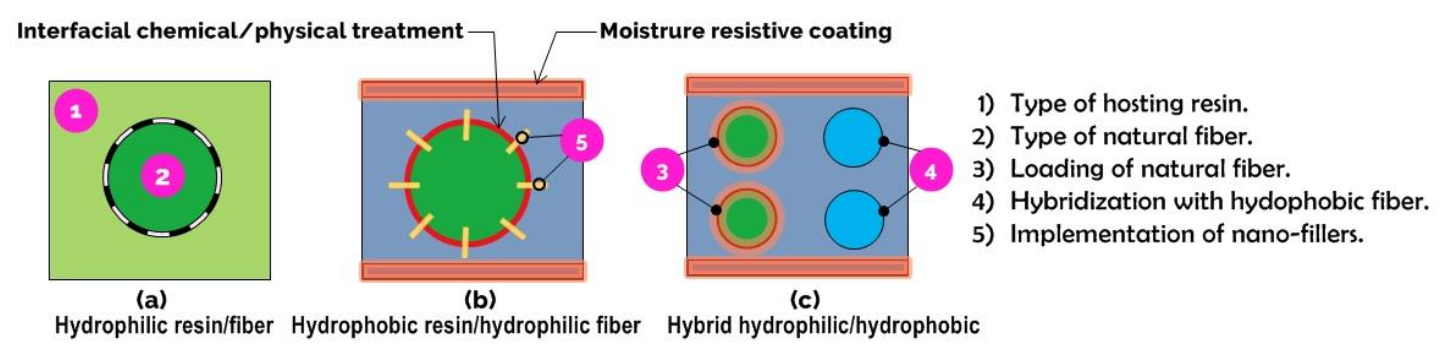

Figure 2. Main parameters affecting the efficiency of chemical/physical treatments.

\section{The Treatment Types of Natural Composites}

The surfaces of natural fibers are composed of non-cellulosic substances (lignin, hemicellulose, and pectin) and waxes, which prevent fibers from forming adequate adhesion with the hosting matrix. It is recommended to increase the hydrophobicity of the natural fibers in order to produce natural composites with improved mechanical, tribological, and moisture absorption properties. This can be achieved through introducing the surfaces of natural fibers to physical and chemical treatments [78-81]. Treating the natural fibers with chemical and physical methods eliminates the hydrophilic elements from the surface of the fiber. Hence, the content of lignin is increased, leading to the considerable reduction of the fiber's hygroscopic behavior $[82,83]$. The effect of various types of treatments on enhancing the moisture absorption behavior of natural composites can be realized through exploring the improvement attained on the moisture absorption behavior for different types of natural composites, as shown in Figure 3. It can be noted that some types of treatments have negative consequences on the 
water uptake behavior of some composites, such as jute fiber/UP and sisal fiber/starch, which are treated with hot water and alkalization methods, respectively. This reduction can be attributed to the removal of hydrophobic components such as lignin from the treated fiber's structure, which as a result induces the composite to absorb a higher amount of moisture.

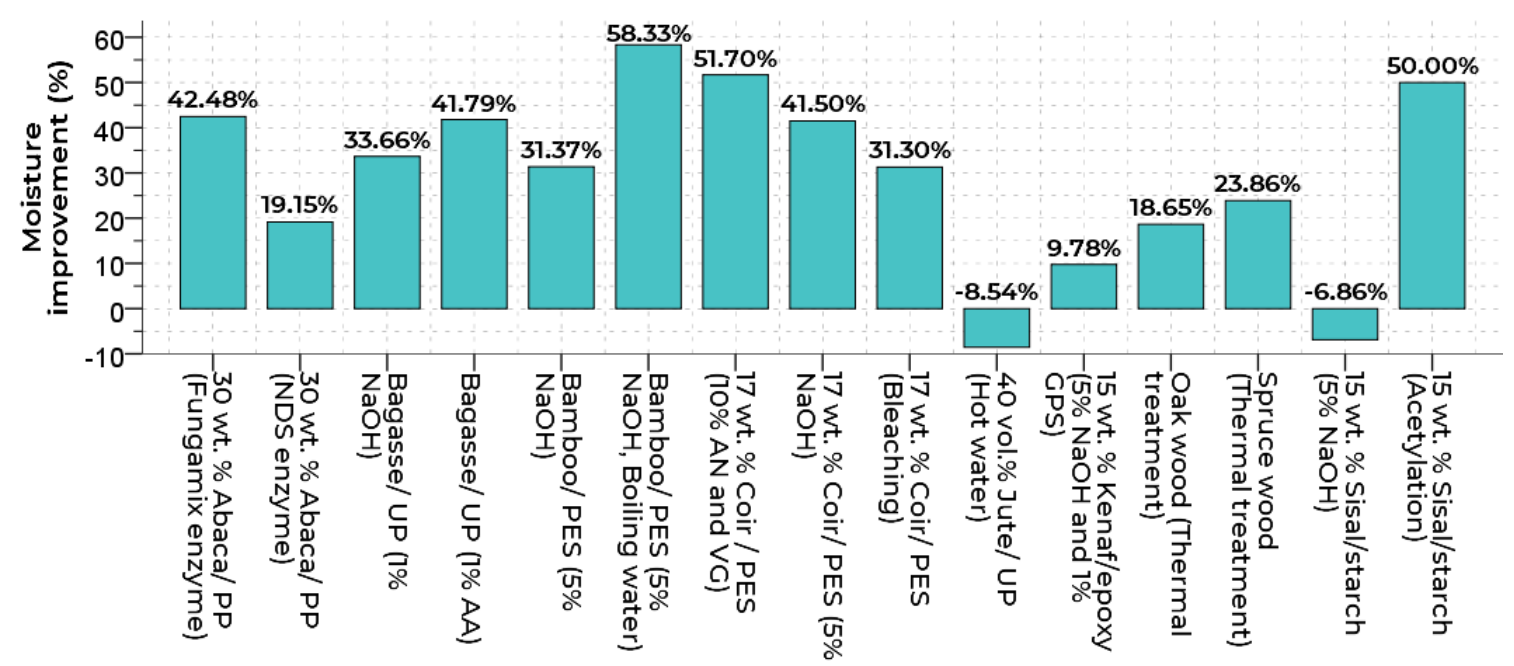

Figure 3. The effect of different treatment methods on the improvements attained on the moisture absorption behavior of natural composites. $30 \mathrm{wt}$ \% Abaca/PP (1920 h) [84], Bagasse/UP (720 h) [85], Bamboo/PES (1440 h), immersion in boiling water (2.0 h) [86], 17 wt. \% Coir/PES (1440 h) [87], 40 vol. \% Jute/UP (960 h) [88], 15 wt. \% Kenaf/epoxy (816 h) [81], Oak wood (168 h) [89], Spruce wood (168 h) [89], 15 wt. \% Sisal/starch [90].

The moisture absorption treatments are classified into chemical and physical treatments according to their capabilities of changing the chemical composition and structure of natural composites. The chemical and physical treatments that are commonly used to improve the moisture absorption properties of various types of natural composites are discussed in detail in Sections 2.1 and 2.2, respectively.

\subsection{Chemical Treatments}

The chemical treatments can eliminate the $\mathrm{OH}$ coating from the natural fibers and increase the roughness of fiber surface, leading to a noticeable increase in the mechanical interlocking of the natural fiber with the hosting resin [91-93]. With increasing chemical treatment time, the treated fibers exhibited a significant increase on the surface roughness, and the impurities are eliminated to the highest extent, as shown in Figure 4. It can be inferred from the scanning electron microscope (SEM) images of sisal fibers treated with sodium bicarbonate that a noticeable reduction occurred at the fiber diameter for all of the treated fibers due to the elimination of a specific portion of the natural oil covering the surface the fiber's cell wall in addition to lignin, waxy, and hemicellulose substances. Upon the removal of lignin and hemicellulose from the fiber's structure, the internal constraints located within the interfibrillar region are released. Hence, the cellulose fibrils reorganized themselves into a highly compacted structure, leading to a higher dense packing of cellulose fibrils' chains [94].

The natural fibers can be treated through using one of the following chemical treatments: 


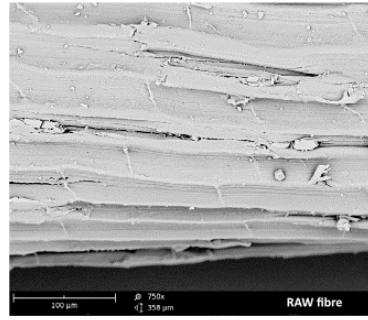

(a)

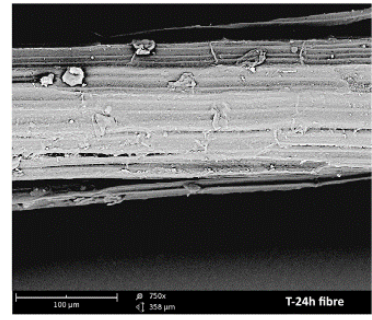

(b)

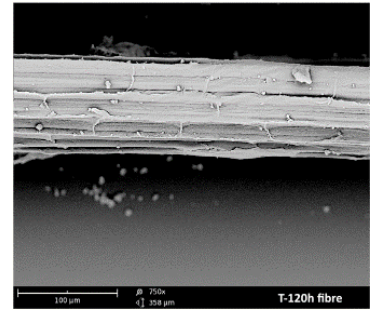

(c)

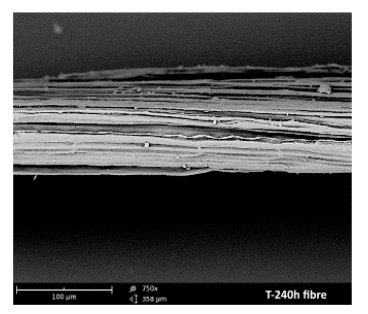

(d)

Figure 4. SEM image for sisal fiber with different treatment times: (a) Raw, (b) $24 \mathrm{~h}$, (c) $120 \mathrm{~h}$, and (d) $240 \mathrm{~h}$. Reproduced with permission from [94].

\subsubsection{Acetylation}

Applying acetic anhydride treatment to various types of natural fibers can enhance the moisture resistance properties of natural composites. This improvement is attributed to the elimination of lignin and hemicellulose elements from the treated fibers $[16,95]$. Through the acetylation process, the acetyl groups $\left(\mathrm{CH}_{3} \mathrm{CO}\right)$ react with the hydroxyl groups $(\mathrm{OH})$ of the fiber, which makes the surface of the fiber more hydrophobic $[96,97]$.

\subsubsection{Benzoylation}

In this treatment, fibers are treated with alkali solution with a specific $\mathrm{NaOH}$ concentration first, followed by benzoyl chloride treatment. Then, the $\mathrm{OH}$ groups of the fibers are further substituted by the benzoyl group, which then attaches to the backbone of the cellulose [16].

\subsubsection{Treatment by Peroxide}

The peroxide treatment includes the grafting of PE adheres onto the surface of the natural fibers. The peroxide treatment mechanisms include an alkali pretreatment on the fibers, which are then immersed with dicumyl or benzoyl peroxide (about $6 \%$ concentration) in acetone aqueous for a duration of $30 \mathrm{~min}[16,98]$.

\subsubsection{Treatment by Isocyanate}

The chemical bond formed by isocyanate offers a strong covalent linkage between the matrix (especially thermoplastic one) and the fiber. Furthermore, the moisture that exists on the fiber surface reacts with isocyanate and forms urea, which can react more with the hydroxyl groups of the celluloses. This secondary reactions lead to better linkage between the fiber and matrix, and better moisture barrier properties of the fiber $[16,99]$.

\subsubsection{Acidic Treatments}

In this treatment, different types of acids can be used in order to improve the hydrophobic nature of natural fibers such as stearic, hydrochloric, and acrylic acids. The hydrophilic hydroxyl groups of the fibers react with the carboxyl group of the treating acid and consequently enhance the moisture resistance properties. Moreover, the treating acid enhances the mechanical interlocking of the fiber with the hosting matrix through the fibrillation of the fiber bundle [16,100]. However, removing non-cellulosic elements in a wide range through treatments such as hydrochloric acid induces the degradation of the fibers and considerably impacts the transverse mechanical properties of the composites [101,102].

\subsubsection{Alkalization}

This treatment is the most feasible method that can effectively emphasize the interfacial adhesion between the fiber and matrix, leading to significant improvement on the moisture absorption properties 
of the treated composite [15,103-106]. The hydrophilic hydroxyl groups located at the surface of natural fibers can be reduced through treating them with $\mathrm{NaOH}$ solution. Furthermore, this treatment can eliminate a specific portion of the lignin, wax, pectin, hemicellulose, and oil that is covering the materials [107]. After applying $\mathrm{NaOH}$ treatment, the surface of the fiber becomes rougher and more organized because of the removal of microvoids, which enhances the capacity of stress transfer among the ultimate cells $[17,108]$. Furthermore, it mitigates the diameter of the fiber, increasing the aspect ratio of the fiber. This participated in increasing the surface area effectively for better adhesion with the reinforced matrix. Treating natural fibers with a lower concentration of alkaline solution is found to be better than treating them with higher concentration solutions $[109,110]$. Treating hemp, coir, kenaf, and alfa fibers with $5-6 \%$ of $\mathrm{NaOH}$ cleans the fiber surface through eliminating the amorphous compounds, and increases both the crystallinity index of the fiber bundle and the hydrogen groups at the fiber surface [111-116]. The treatment time and concentration of alkali can adversely influence the properties of the fibers. If the fibers are not washed adequately, the alkali will progress to degrade the treated fibers long after exposure, leading to the considerable breakdown and swelling of the fiber. Furthermore, there are some undesirable consequences associated with the alkalization process, such as high surfactant content, high $\mathrm{pH}$ values, and contaminated wastewater remaining after treatment $[60,117]$. Consequently, the concentration of alkaline solution should be carefully selected in order to avoid the deterioration of the structural properties of natural fibers such as the considerable fibrillation of the natural fiber bundle, which occurs when the fiber is treated with a higher concentration of $\mathrm{NaOH}$, as demonstrated in Figure 5 [118].

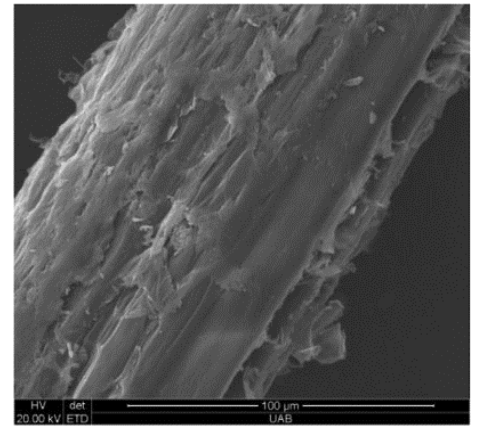

(a)

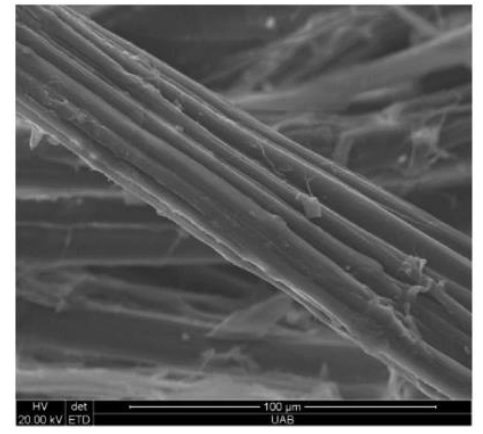

(b)

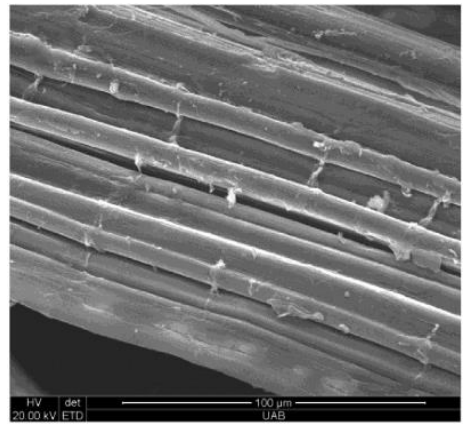

(c)

Figure 5. The alkalization effect on fibrillation of hemp fiber: (a) raw, (b) $5 \mathrm{wt}$. \% NaOH and (c) $10 \mathrm{wt}$ \% $\mathrm{NaOH}$. Reproduced with permission from [119].

The improvement that can be achieved from alkalization is subjected to the type of natural fiber. For example, treating the water hyacinth fiber-reinforced UP composite with alkali solution does not change the moisture absorption resistance considerably. This can be attributed to the physical effect that take place in the cell wall of the fiber, creating many more micro and nano hollow cavities, crevices, and porosities that enable the fiber to absorb more moisture [120]. The alkalization has an adverse effect on the moisture absorption properties of specific types of natural fibers [81]. For instance, treating sisal fibers with $5 \% \mathrm{NaOH}$ makes the sisal/starch composite absorb a higher amount of moisture relative to the untreated one, while there is a slight reduction noticed in the diffusivity of the treated composite [121]. The alkalization of banana fibers swells the structure of the treated fiber because of considerable alteration in the morphology, structure, dimensions, and mechanical properties [122]. The combination of silane and alkali treatments exhibits a superior enhancing effect on the moisture absorption properties relative to single treatment [123-125]. More details about different types of silane coupling agents are discussed in the next section. 


\subsubsection{Coupling Agents and Grafting}

The coupling agent promotes the interfacial interaction between the polymer matrix and natural fibers, enhancing the compatibility at the matrix-fiber interface. Strengthening the interfacial adhesion reduces the water uptake behavior, since the gaps and voids content at the fiber-matrix interface is minimized to the highest extent. Silane coupling agents introduce improvement to the moisture absorption behavior and diffusivity of different natural composites up to $89 \%$ and $96 \%$, respectively, as demonstrated by the values listed in Table 1 [126-128]. The coupling agent can serve two main functions: it reacts with the functional groups of the matrix, and then it reacts with the $-\mathrm{OH}$ groups found in cellulose. Specifically speaking, the silane molecule links between cellulose and resin by creating a chemical bond with the cellulose surface through a siloxane bridge, while its organofunctional group bonds to the polymer matrix [129]. This reaction process reduces the number of hydroxyl groups found on the fiber surface. The chains of hydrocarbon emerging from silane application prevent the fiber swelling through the cross-linked network that is formed due to covalent bonding between the fiber and matrix. The interaction between silane-treated fibers and the hosting matrix is much stronger than that of alkali-treated ones $[16,130]$.

Table 1. The improvements on moisture absorption properties attained from using coupling agents.

\begin{tabular}{|c|c|c|c|c|c|}
\hline References & Composite & $\begin{array}{c}\text { Immersion } \\
\text { Time (Hours) }\end{array}$ & $\begin{array}{l}\text { Coupling } \\
\text { Agent }\end{array}$ & $\begin{array}{c}\text { Moisture } \\
\text { Improvement \% }\end{array}$ & $\begin{array}{c}\text { Diffusivity } \\
\text { Improvement } \%\end{array}$ \\
\hline [131] & $\begin{array}{l}50 \text { wt. } \% \text { Alfa } \\
\text { pulps/LDPE }\end{array}$ & 480 & $\begin{array}{c}\text { HDS } \\
\text { MPS } \\
\text { MRPS }\end{array}$ & $\begin{array}{l}37.14 \\
25.71 \\
14.29\end{array}$ & - \\
\hline [86] & $\begin{array}{l}\text { Bamboo } \\
\text { matting/polyester }\end{array}$ & $1440 / 2^{1}$ & $\begin{array}{c}\text { APTES } \\
\text { TMSPMA } \\
\text { VTMOEO } \\
\text { TESPTS } \\
\text { APTMOS } \\
\text { OTMOS }\end{array}$ & $\begin{array}{c}62.75 / 89 \\
37.25 / 55.5 \\
52.94 / 84.2 \\
13.73 / 24.5 \\
31.37 / 66.67 \\
50.98 / 36.67\end{array}$ & $\begin{array}{l}95.38 \\
87.05 \\
95.81 \\
16.01 \\
55.53 \\
90.48\end{array}$ \\
\hline [132] & 30 wt. \% Ijuk/PP & 240 & VTMS & 5.22 & - \\
\hline [25] & Jute/epoxy & $336^{2}$ & GLYMO & 8.0 & - \\
\hline$[133]$ & 10 wt. \% Luffa/PP & 960 & $\begin{array}{l}\text { MS } \\
\text { AS }\end{array}$ & $\begin{array}{c}34.3 \\
39\end{array}$ & - \\
\hline
\end{tabular}

${ }^{1}$ Immersion in boiling water. ${ }^{2}$ Immersion time for one cycle of absorption and desorption of moisture.

Treating natural fibers with different types of silane coupling agents considerably reduces the water uptake behavior of the treated fibers. Treating sisal fibers with $1 \%$ of an MPS coupling agent reduces the water absorption from $123.8 \%$ to $64.4 \%$ and the equilibrium moisture content from $12.8 \%$ to $1.7 \%$. Vinyltrimethoxy silane, $y$-aminopropyl triethoxy silane, and GPS are silane coupling agents that can be used to effectively reduce the water uptake tendency of oil palm, sisal, and jute fibers, respectively [128]. The MA grafted polymer is one of the most common methods used to reduce the moisture absorption capability of natural composites [133]. Moreover, graft copolymerization reduces the hydrophilic properties of biopolymers without altering their inherent properties [134]. The MA can reduce the hygroscopic behavior through the reaction with - $\mathrm{OH}$ groups at the surface of the natural fiber to create ester linkages, which slightly decreases the moisture absorption values [135]. The grafting of MA is frequently used with PP resin, which has an outstanding improving effect on the moisture absorption properties, as can be inferred from the values listed in Table 2.

It can be concluded from the values listed in the table above that the alkalization of fibers prior to grafting induces the composite to absorb a higher amount of moisture relative to silane-treated fibers. Removing the non-cellulosic elements of natural fibers after alkalization influences the capability of MA to link the fibers with the hosting resin. 
Table 2. The effect of MA grafting on moisture absorption properties.

\begin{tabular}{|c|c|c|c|c|c|}
\hline References & Composite & Aging Conditions & Coupling Agent & $\begin{array}{l}\text { Moisture Content \% } \\
\text { (Untreated) }\end{array}$ & $\begin{array}{c}\text { Diffusivity, } \mathrm{m}^{2} / \mathrm{s} \\
\text { (Untreated) }\end{array}$ \\
\hline$[84]$ & 30 wt. $\%$ Abaca/PP & $\begin{array}{l}95 \% \mathrm{RH} \text { at } 50{ }^{\circ} \mathrm{C} \\
\text { for } 1920 \mathrm{~h}\end{array}$ & MAPP & $9.62,(15.09)$ & - \\
\hline [136] & 50 wt. \% Kenaf/PP & $24 \mathrm{~h}$ & 2 wt. $\%$ MAPP & 1.05 & - \\
\hline [52] & Jute/PP & $\begin{array}{c}95 \% \mathrm{RH} \text { at } 23{ }^{\circ} \mathrm{C} \\
\text { for } 18 \mathrm{~h}\end{array}$ & 2 wt. $\%$ MAPP & 21.5 & - \\
\hline [133] & 10 wt. \% Luffa/PP & $960 \mathrm{~h}$ & 2 wt. $\%$ MAPP & 28.4 & - \\
\hline \multirow{6}{*}{ [77] } & \multirow{6}{*}{$\begin{array}{l}50 \text { wt. \% Rice } \\
\text { husks/PP }\end{array}$} & & Untreated fiber + 2\% MAPP & 9.91, (11.39) & $\begin{array}{c}1 \times 10^{-13} \\
\left(2.37 \times 10^{-13}\right)\end{array}$ \\
\hline & & & $\begin{array}{c}\text { Untreated }+2 \% \text { MAPP }+1 \% \\
\text { SEBS-g-MA }\end{array}$ & 9.38 & $8.37 \times 10^{-14}$ \\
\hline & & & $\mathrm{NaOH}+2 \% \mathrm{MAPP}$ & 15.31 & $1.50 \times 10^{-13}$ \\
\hline & & & $\begin{array}{c}\mathrm{NaOH}+2 \% \mathrm{MAPP}+1 \% \\
\text { SEBS-g-MA }\end{array}$ & 14.35 & $1.33 \times 10^{-13}$ \\
\hline & & & Silane $+2 \%$ MAPP & 9.45 & $4.65 \times 10^{-14}$ \\
\hline & & & $\begin{array}{c}\text { Silane }+2 \% \text { MAPP }+1 \% \\
\text { SEBS-g-MA }\end{array}$ & 9.71 & $5.65 \times 10^{-14}$ \\
\hline [126] & $\begin{array}{l}60 \text { wt. } \% \text { WF } / P P \\
60 \text { wt. } \% \text { OSF } / P P\end{array}$ & $\begin{array}{c}23{ }^{\circ} \mathrm{C} \text { and } 50 \% \text { of } \\
\mathrm{RH} \text { for } 48 \mathrm{~h}\end{array}$ & $5 \%$ MAPP & $\begin{array}{l}11.57,(14.57) \\
9.55,(13.78)\end{array}$ & - \\
\hline [137] & $\begin{array}{l}15 \text { wt. \% Wood } \\
\text { flour } / \mathrm{PP}\end{array}$ & $96 \mathrm{~h}$ & $\begin{array}{c}1 \text { wt. } \% \text { A-1100 } \\
1 \text { wt. } \% \text { A-174 } \\
5 \text { wt. \% MAPP } \\
1 \% \text { A- } 1100+5 \text { wt. } \% \text { MAPP }\end{array}$ & $\begin{array}{c}1.29,(1.39) \\
1.14 \\
1.20 \\
1.09\end{array}$ & - \\
\hline
\end{tabular}

\subsubsection{Polymeric Coatings}

In order to prevent the fast diffusion of water molecules into the composite structure specifically in the interfacial region between the fiber and matrix, it is recommended to apply a suitable thickness of resin-rich surface at the composite surface and to keep this resin layer intact and free of cracks throughout the service life of the composite [138]. Natural composites can be coated through films fabricated from either synthetic polymers or natural materials, which proved their capability on reducing the moisture absorption [139]. Applying coatings to the natural fibers introduces a higher degree of moisture resistance relative to chemically treated ones [56]. Plastic adhesive tape of PP with a thickness of $0.1 \mathrm{~mm}$ is used to coat the short jute fiber/PLA composite. It is demonstrated that the water uptake behavior can be efficiently retarded after applying this coating [140]. Acrylated epoxidized soybean oil polymer is used as a coating for the flax fiber-based composite. It is found out that the moisture absorption property is enhanced through the applied coating [141]. A film composed of PE is implemented to coat the hemp fiber-based composite. After applying the coating, the water uptake behavior is enhanced considerably. The PE film inhibits the water molecules from penetration into the composite, since the polymer film has no tendency to absorb moisture. The water uptake test showed that the moisture absorption is reduced by $88.5 \%, 84.8 \%$, and $68.5 \%$ when composite samples are exposed to ageing conditions for $2 \mathrm{~h}, 24 \mathrm{~h}$, and $120 \mathrm{~h}$, respectively [142]. A jute fiber-reinforced epoxy composite is coated with acrylic paint and epoxy resin. Relative to the raw composite, the applied coatings increase the moisture resistance of the treated composite. The alkalization of natural fibers prior to the application of coatings increases the composite's capability to resist moisture [143]. It is important to highlight that there are specific types of coatings that have an adverse effect on the moisture absorption resistance and consequent fiber swelling. For example, treating the surface of oil palm ash, which is used to reinforce the natural rubber composite, with liquid epoxidized natural rubber retards the crosslink density of the filler with the hosting matrix, and mitigates both the moisture absorption and swelling resistances of reinforcing fillers [144].

\subsection{Physical Treatments}

The physical methods such as the fabrication of hybrid yarns, calendaring, thermal treatment, and stretching do not alter the chemical composition of natural fiber. Physical treatments change 
the surface and structural properties of the fiber, and hence affect the mechanical bonding with the hosting matrix [145]. Thermal treatment can be used to treat wood composite panels in order to impede water molecules from penetrating inside the composite structure. This treatment increases the compactness of the wood structure both in the panel cross-section as well as on the surface due to the macromolecular rearrangement and water loss. This compactness provides the effective stabilization of the wood assembly under water aging circumstances [89]. Fewer hydrophilic fibers can be produced by a retting process where a high amount of waxes can be deposited on the fiber's surface. The steam explosion technique (STEX) competes effectively with the retting process in terms of producing fibers with less hydrophilicity. During the STEX process, additives and steam are diffused into the fiber interspaces of green fiber bundles due to the applied process conditions of increased temperature and adequate pressure. Consequently, the center lamella can be improved at ideal conditions of reaction. The subsequent abrupt relaxation of the steam leads to an efficient breaking up of the green bast fiber, which results in substantial decomposition into individual fibers (DDA). Relative to raw fibers, Duralin and DDA-treated fibers (both of them retrieved from the STEX process) clearly exhibit the most hydrophobic surfaces [146]. Manipulating the natural fillers with plasma treatment increases their hydrophilic behavior, providing them with better sorption aspects. This treatment eliminates part of the lignin content, transforming it to a surface with a higher degree of hydrophilicity $[147,148]$. Through oxygen plasma treatment, different functional groups can be used to introduce different functional groups on the surface of natural fibers, and these functional groups can establish strong covalent bonds with the matrix, leading to strong interfacial adhesion between the fiber and matrix. Furthermore, plasma treatment increases the surface roughness and leads to better adhesion with the hosting matrix through mechanical interlocking $[149,150]$. The treatment by fungi can be employed to eliminate the non-cellulosic constituents such as wax from the surface of the fiber by the effect of specific enzymes. The fungi generate hyphane, which creates tiny holes on the surface of the fiber and generates a coarse interface for efficient interlocking with the matrix [16,84]. Ideally, this treatment method leads to a noticeable increase in the surface hydrophilicity due to the elimination of hemicellulose and lignin, leaving the cellulosic backbone exposed to the environment [151]. It is important to realize that the physical treatment methods such as hot water, enzyme, and electron beam radiation compromise the flexural properties of composites due to the over extraction of the fiber's extractives. For example, enzymes severely dissolute the hemicellulose as an interfibrillar matrix, which leads to a great reduction of the fiber's properties. However, chemical treatment techniques provide the treated fibers with more dimensional stability, higher resistivity toward fungal decay, and moisture absorption [124].

\section{Type of Hosting Matrix}

The efficiency of the physical and chemical treatments applied on natural fibers is largely affected by the structure and type of hosting matrix. Polymeric and cementitious matrices are the most frequently hosting mediums used in the fabrication of natural composites. In the subsequent sections, complete discussion about the moisture absorption behavior of these matrices and their composites is developed in Sections 3.1 and 3.2.

\subsection{Polymeric Matrix}

Thermoplastic resins have various advantages relative to thermoset polymers in the fabrication of biocomposites such as the ease of molding complex parts, low processing, and design flexibility. $\mathrm{PP}$ is the most familiar thermoplastic used in the fabrication of natural composites due to its good mechanical aspects, relative high temperature resistance, reasonable impact resistance, outstanding processibility, and low density [152]. Polyvinyl chloride, PE, PP, and polystyrene are frequently used as thermoplastic hosting matrices for natural fibers. Epoxy, VE, PES, and phenol formaldehyde are thermoset matrices, which can be embedded with natural fibers [153]. According to Figure 6, the type of polymeric resins and the duration of immersion of these resins in water play a key role 
in controlling the equilibrium moisture content penetrated in the polymer matrix. It can be inferred from the same figure that epoxy and PP exhibit an optimum stable performance at both short and long immersion durations compared to other thermoset and thermoplastic resins, respectively. Additionally, the HDPE experiences a considerable change in moisture absorption behavior when the duration of water immersion is increased from $24 \mathrm{~h}$ to $48 \mathrm{~h}$.

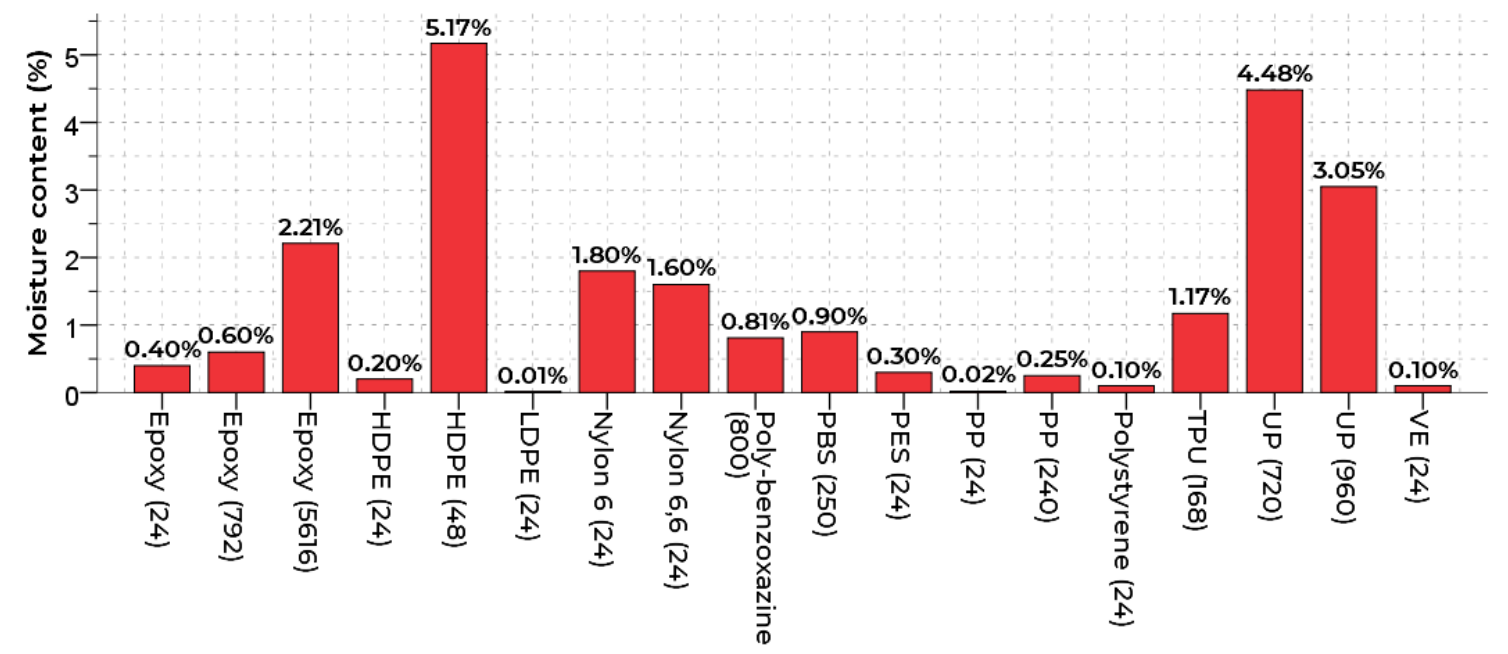

Figure 6. The equilibrium moisture content for most widely used polymers in natural composites. Epoxy (24 h) [78], epoxy (792 h) [76], epoxy (5616 h) [154], HDPE (24 h) [78], HDPE (48 h) [155], LDPE (24 h) [78], nylon 6 (24 h) [78], nylon 6,6 (24 h) [78], polybenzoxazine (800 h) [156], PBS (250 h) [157], PES (24 h) [78], PP (24 h) [78], PP (240 h) [132], polystyrene (24 h) [78], TPU (168 h) [158], UP (720 h) [85], UP (960 h) [88], and VE (24 h) [78].

The biopolymer matrix has a higher tendency to absorb moisture relative to its synthetic counterpart. The water molecules can penetrate into the most of organic polymers, leading to significant alteration in their mechanical, chemical, and thermophysical properties. The major consequence of the moisture absorption is on the polymer itself through saponification, plasticization, hydrolysis, and other degradation mechanisms, leading to both irreversible and reversible modifications in the structure of the polymer [138]. Jute fibers are used to reinforce bio and synthetic epoxy resins in order to investigate the moisture absorption effect on the properties of fully biodegradable composite. It is demonstrated that the type of the epoxy has a significant effect on the water uptake content of the composite. The investigations show that the fiber swelling and moisture absorption are higher in the bio-epoxy-based composite relative to the synthetic one. The higher swelling rate noticed for the fully green composite is justified, since the bio-epoxy contains a specific percentage of cellulose [159]. Generally, soy protein resins absorb a higher quantity of water, which mitigates their mechanical aspects. The moisture absorption characteristics of soy protein can be significantly improved through immersing the protein film in benzilic acid [60]. The compacted structure of the VE polymer justifies the lower coefficient of water diffusion, higher strength, chemical stability, and stiffness of its composites when they are immersed in water [160]. For example, the sisal fibers/VE composite displays $24 \%$ lower moisture absorption at equilibrium relative to the sisal/epoxy composite [161]. Thus, it can be concluded that the variances in moisture absorption behaviors among polymers are attributed to the degrees of crystallinity, hydrophobicity, and structure compactness of the hosting resins [162].

The moisture absorption properties of polymeric resins can be improved through increasing their stiffness, reinforcing them with synthetic fillers, and finally through blending them with proper resins characterized with low hydrophilicity [163]. For instance, the resistance of PLA toward weathering conditions, including moisture absorption, can be enhanced through reinforcing it with specific loadings of synthetic fibers $[54,164,165]$. However, the incorporation of natural fillers such as natural 
rubber into a PLA/rice starch composite introduces moderate enhancements in tensile properties, but it improves the biodegradability of the PLA/rice starch composite when it is exposed to a humid environment [166]. Combining PP with polyamide-6 is applied commonly to reduce both the weight of the resulting composite and its moisture absorption tendency. PP is characterized by low cost, density, and high water uptake resistance, while the polyamide-6 is known for its high affinity for moisture and dimensional stability [167]. The micro-cracking of the matrix originating from freezing and fiber swelling rarely takes place when the hosting matrix is characterized with high ductility such as PP. However, the thermosetting resins such as UP have a high degree of brittleness, and hence cracks propagate quickly inside their structure [168].

\subsection{Cementitious Matrix}

The cumulative effect of hydroxyl groups, cell wall pores, and open lumen makes the natural fibers susceptible to water sorption, which induces the dimensional instability. The moisture absorption has a considerable effect on the mechanical strength of the natural fiber-reinforced cement composite $[169,170]$. The cyclic wetting and drying of natural fibers at temperatures exceeding $70{ }^{\circ} \mathrm{C}$ accelerates their degradation in a cement matrix more efficiently compared to static aggressive aging conditions. Compared to natural fibers immersed in distilled water, the moisture absorption content of fibers soaked in $\mathrm{Ca}(\mathrm{OH})_{2}$ liquid is higher. The durability of cement-based composites in a humid operating environment has fundamental importance for applications in decoration, repair, and construction. The improvement of moisture resistance is attributed to the coupled changes of the matrix surface property and the microstructure of the cementitious composite. The degradation of natural fibers in a cement matrix passes through the following steps: (i) the exposure of holocellulose resulting from the degradation of lignin and the portion of hemicellulose; (ii) the reduction of the stability and integrity of cell walls originating from the degradation of hemicellulose; (iii) the dispersion of cellulose microfibrils emerging from the degradation of intramolecular hydrogen bonding; (iv) the entire degradation of cellulose microfibrils resulting from the alkaline hydrolysis of amorphous components. There are different techniques that can be used to reduce the degradation of natural fibers in a cement matrix, such as:

1. Managing the value of $\mathrm{pH}$ related to the pore solution at relatively low levels [171,172].

2. Combining pozzolanic additives, namely metakaolin and silica fume, with natural fiber-based cement composites [173].

3. Incorporating nano reservoir silts within the binders of the composite [174].

4. Applying a polymeric coating on the surface of the natural fiber. The raw natural fiber is incapable of developing a compact interface of the fiber-cement composite due to the hydrophilic nature of the fiber. The polymer molecules diffuse into the fibers, particularly between the filling lumens and fiber cells, reducing the moisture absorption. Consequently, the application of a polymer coating decreases the concentration of $\mathrm{OH}$ and enhances the strength of the natural fiber, which improve its interfacial integrity and bonding strength $[175,176]$.

5. Reinforcing cement with mineral fillers such as basalt fibers, which can be classified as non-hazardous and environmentally friendly substances [177].

However, the effect of the hosting matrix type should be addressed with the type of natural fiber, which is used to improve its structural performance, in order to determine the degree of compatibility at the interfacial region between the fiber and matrix. More information about the effect of reinforcing fiber is discussed in detail through Section 4.

\section{Type of Natural Fibers}

The natural fibers have varying moisture absorption behavior, since they have different interfacial bond strengths in addition to various morphologies and chemical compositions in terms of lignin and hemicellulose loadings [75]. The chemical composition and structure of jute fibers make them 
different from other natural fibers, since they absorb moisture, and its moisture regain characteristic is very high. For example, jute fibers absorb a lower amount of moisture relative to banana fibers at the same immersion period [178]. Additionally, due to the porous configuration of the ground tissues, bamboo fibers absorb a higher amount of moisture relative to more common bast fibers such as hemp, kenaf, and flax fibers $[179,180]$. The OSF-reinforced PP composite shows lower moisture absorption relative to the wood-based PP composite. This behavior can be attributed to the aspect ratio and morphology of OSF, which are quite different from wood fillers, even though both fillers have the same chemical compositions [126]. The type of natural fiber has a more significant effect on water uptake behavior compared to the type of chemical and physical treatment conducted on the natural fiber [181]. Biofibers such as cotton burr and stem, guayule bagasse, and oak fibers are used to reinforce HDPE resin modified with two types of coupling agents in order to prepare biofiber-based composites. The water uptake test shows that the coupling agent has a minimal effect on the moisture absorption of the composite. The guayule bagasse fibers have a great influence on decreasing the moisture absorption tendency of the composite [182]. The effect of the natural fiber types on the efficiency of the moisture resistance treatments can be fully realized through exploring the percentage of improvements on moisture absorption behavior, as shown in Figure 7.

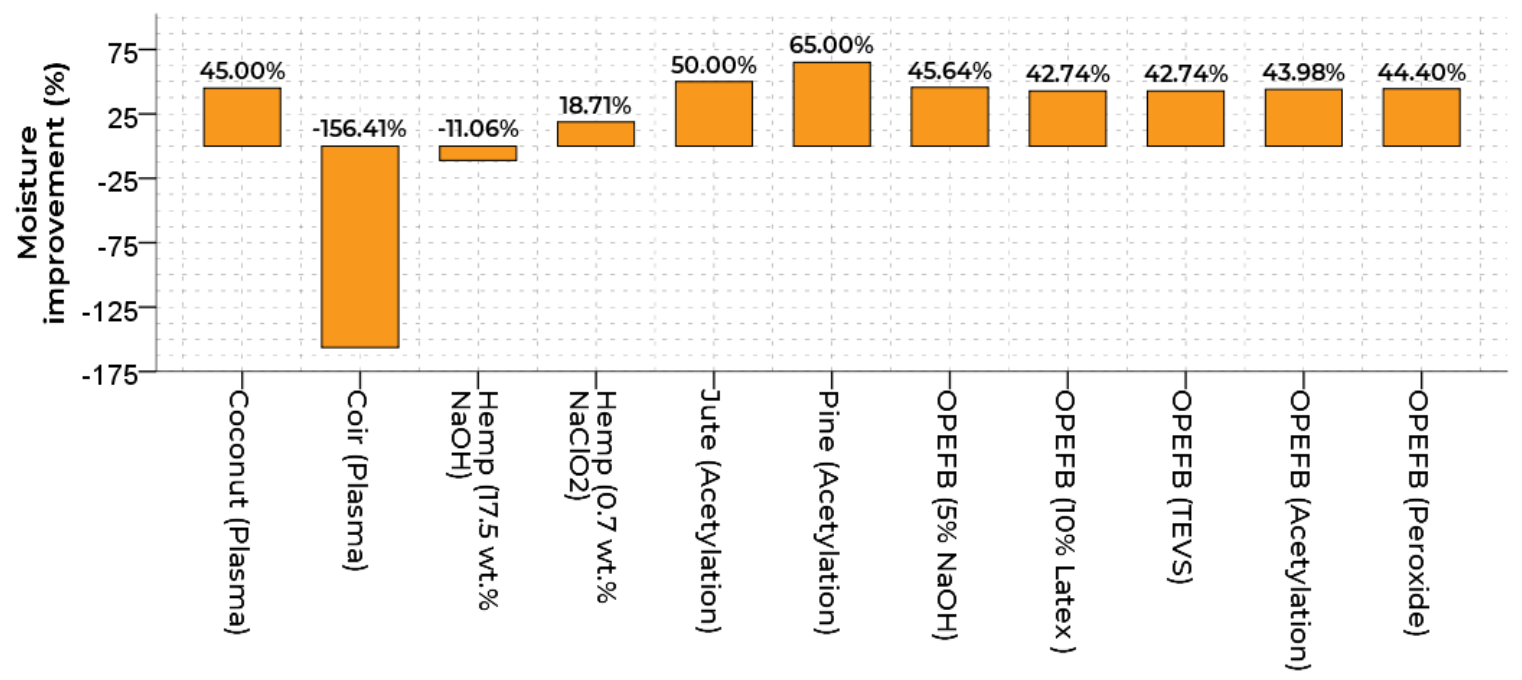

Figure 7. The improvement percentage of different treatments on moisture absorption behavior of natural fibers. Coconut plasma [147], coir (plasma) [183], hemp (17.5 wt. \% NaOH) [184], hemp (0.7 wt. \% $\mathrm{NaClO}_{2}$ ) [184], jute (acetylation) [96], pine (acetylation) [96], OPEFB (5\% $\mathrm{NaOH}$ ) [70], OPEFB (10\% latex) [70], OPEFB (TEVS) [70], OPEFB (acetylation) [70], and OPEFB (Peroxide) [70].

It can be inferred from the values clarified in the figure above that the samples of OPEFB fiber, which are treated with five different types of treatments, exhibit approximately the same percentage of improvement on moisture absorption behavior. However, treating coconut and coir fibers with the same moisture treatment technique (plasma method) leads to great variation between these two fibers in terms of moisture absorption resistance's properties. This behavior implies that applying plasma treatment on different types of natural fibers having various chemical compositions could introduce adverse impact on the moisture absorption behavior of the fiber under treatment if the moisture treatment technique excessively eliminates non-cellulosic components from the fiber structure such as lignin, which consequently induces the natural fiber to absorb higher quantities of moisture from the surrounding environment. In next sections, the most commonly used natural fibers are discussed in terms of their effects on mitigating the moisture quantities absorbed by chemically/physically treated composites. 


\subsection{Cellulose Fiber Composites}

The properties of pure PLA resin can be easily deteriorated at high temperature in the existence of residual moisture or water. Therefore, cellulose fibers are commonly used to reinforce PLA resin composites in order to increase the resistance of PLA resin under hygrothermal conditions. The cellulose fiber/PLA composites show a poor adhesion at the cellulose fiber-PLA interface, but their structures exhibit well-dispersed morphology. To improve the water uptake behavior and mechanical properties of cellulose fiber composites, the surfaces of the fibers are coated with suitable coatings, chemically/physically treated, or hybridized with secondary nanofillers [185]. For example, the silane coupling agent is used to improve the mechanical and physical properties of the cellulose nanofibers reinforced bio-epoxy composite. The treated composite exhibits the lowest content of voids relative to the raw composite due to the effect of silane treatment on improving the wettability of cellulose nanofiber in the bio-epoxy resin [186]. Cellulose fibers are used to reinforce the water-based resin composite. The implementation of water-based resin in fabricating the composite is favorable due to its similarity with cellulose. The moisture absorption of the resulting composite is 100 folds lower than that of the neat cellulose sheet [187].

\subsection{Wood Plastic Composites}

Biopolymers are considered suitable materials to be implemented in manufacturing WPCs, which have the potential to substitute engineered wood and petroleum-based plastics in building construction applications. Nevertheless, the dissemination of WPCs in construction applications is still limited due to the concerns related to its long-term durability, especially in high wet and humidity environments. It was highlighted in the literature that the type of hosting polymer matrix has a considerable effect on the mechanical performance of WPCs. For example, PP-based WPCs have lower resilience properties relative to PHBV-based ones. Furthermore, the performance of chemically treated PP-based WPCs are lower than that of raw PHBV-based WPC reinforced with $20 \%$ of wood powder [188]. The moisture absorption and swelling of WPCs are largely affected by the source of the wood fiber, size of the wood particle, surface treatment of the wood, orientation of the wood fiber, conditioning temperature, exposed surface area of wood fillers, and increased proportionally with the increasing content of these fillers. Composites reinforced with large wood particles exhibit high thickness swelling and water diffusivity. The molecules of water can diffuse in WPCs through the interface between the fiber and the matrix, fiber lumen, and fiber cell $[189,190]$. The penetration of water molecules into the structure of WPCs decreases the mechanical properties of the composite considerably. Wood powder composed of hard particles can effectively increase the stiffness of WPCs. However, when these particles absorb moisture, they become ductile, and hence the stiffness of the composite is reduced. When the WPC is redried, the wood particles are able to regain their hardness, and can contribute efficiently in composite stiffness. However, exposing WPCs to a humid environment leads to the swelling of the wood powder in the hosting resin, leading to the initiation of micro-cracks in the composite structure, which prevents the composite from restoring its original stiffness [191-194]. The fillers of wood powder are qualified candidates to reinforce thermoplastic polymers such as PP, which improves the biodegradability of these polymers. For example, the sawdust-PP composite has a higher degree of biodegradability over neat PP resin due to its accelerated rate of degradation, resulting from hydrolysis and microbial attack [195].

Various techniques have been investigated in the literature in order to improve the resistance of wood fillers toward moisture absorption, including the application of superhydrophobic coatings and using hot water extraction. It is found out that the application of coatings to wood powder has a trivial effect on the moisture absorption behavior [196]. On the other hand, liquid hot water can be used to extract hemicellulose from wood, which improves the moisture absorption resistance of WPC. This improvement can be attributed to the increase in compatibility between the thermoplastic matrix and reinforcing wood fillers [197]. Using coupling agents to treat WPC reduces the moisture absorption, thickness swelling, and moisture diffusion in the composite's structure. The optimum loading of the 
coupling agent can be determined based on the content and size of the wood $[190,198,199]$. Following better processing methods during the manufacturing of WPCs is another route that can be followed to improve the moisture absorption behavior. For example, the water uptake behavior of injection molded PP-based WPC can be effectively improved through increasing the screw speed and residence time during the manufacturing process, which produces small-sized wood particles, leading to a noticeable reduction in the rate of moisture absorption in the range of $10 \%$ up to $40 \%$ without any change in the mechanical properties [200,201]. Moreover, increasing the content of the polymer in WPC improves the weatherability performance of the composite, such as the suppression of surface cracks resulting from various weathering conditions [202].

\subsection{Flax Fiber Composites}

The anisotropy and morphology of flax fibers have a considerable effect on the diffusivity of water. The diffusivity of water across and along the direction of the fibers is considerably higher relative to the diffusivity across the thickness direction [203]. The influence of the moisture absorption during the manufacturing process of flax fiber/UP composite on the interfacial adhesion strength could be limited [204]. The interaction between flax fibers and the PP hosting matrix depends on van der Waals interactions that are sensitive to water. The adhesive pressure originating from residual stress could be released through the effect of moisture plasticizing [205]. Structural damages can be easily initiated in flax fiber-based composites exposed to moisture aging conditions. These damages are motivated by fiber swelling, fiber degradation, the washing out of soluble substances-specifically the cement of the fiber bundle, the poor interfacial strength between the fiber and matrix, and the plasticization of the hosting matrix [5,206-209]. In order to develop economically feasible flax fibers composites characterized with better mechanical and environmental performance, it is recommended to improve the hydrophobic behavior through treating them with appropriate chemical and/or physical treatments [152]. Duralin, peroxide, benzoylation, and the grafting of MA are the most effective treatment methods that can be used to improve the water uptake behavior of flax fibers composites, as demonstrated by the improvement values shown in Figure 8.

The moisture absorption and diffusivity of flax fiber-based composites can be considerably reduced through hybridizing flax fibers with synthetic fibers such as glass fibers. Nevertheless, the hybridization of flax fibers has an adverse effect on tensile strength when the hybrid composite is exposed to a hygrothermal environment characterized with high temperatures and humidity [210]. The thermal treatment of flax fibers can effectively mitigate the swelling of flax fibers and their sensitivity to moisture absorption through changing the chemistry of the fiber without considerably altering the morphology of elementary fibers [211]. The hosting resin contributes effectively to reducing the moisture absorption potential of flax fibers. For example, the PLA matrix decreases the water uptake behavior of flax/PLA composites by around $40 \%$ relative to a neat flax matrix [212]. Twill flax fiber-reinforced thermoplastic resin (acrylic) composites absorb a lower amount of moisture relative to flax fiber-reinforced thermoset (epoxy) composites. This behavior can be attributed to the higher porosity loading of the flax fiber-reinforced epoxy composite relative to the flax fiber-reinforced acrylic [213]. Two flax fiber-based composites of flax/polyurethane and flax/bio-epoxy have been compared in terms of their moisture absorption characteristics. It is found out that polyurethane absorbs a lower quantity of water and at a slower rate than bio-epoxy resin. 


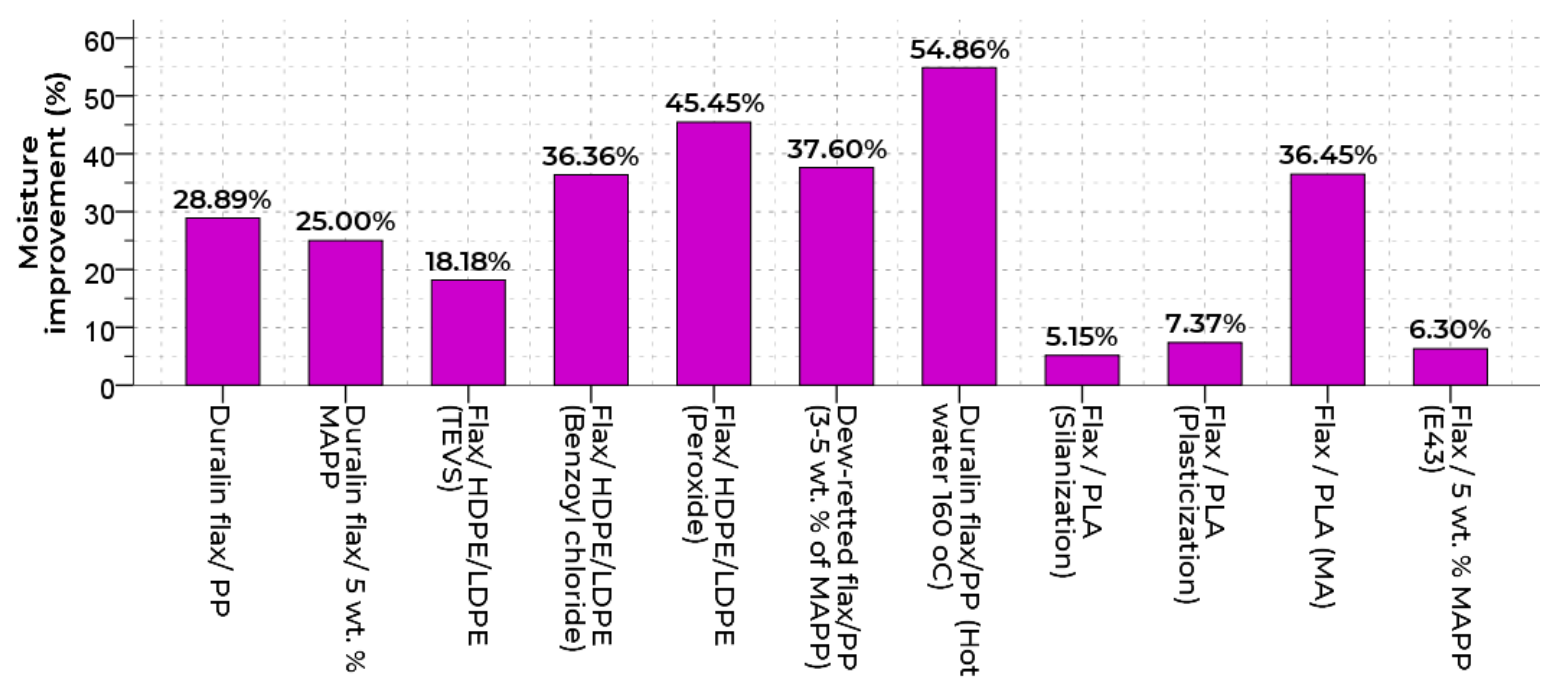

Figure 8. Improvement of the moisture absorption behavior of flax fiber-based composites. 38 vol.\% flax fiber/PP (1440 h) [214], 10 wt. \% flax fibers/HDPE/LDPE (24 h) [215], dew-retted (RFB) flax/PP and Duralin upgraded flax/PP $(\mathrm{RH}=100 \%$ for $4500 \mathrm{~h})$ [146], flax fiber/PLA (408 h) [216], 60 wt. \% short flax fiber bundle/5 wt. \% MAPP (E43) (5040 h) [135].

The chemical bonding between urethane pre-polymer and hydroxyl groups of cellulosic fibers reduces the number of available hydroxyl groups. Therefore, it is recommended to use polyurethane resin as the hosting matrix for most cellulosic fibers in order to attain good durability, moisture resistance, and environmental stability properties [217].

\subsection{Hemp Fiber Composites}

The packing arrangement and chemical treatment such as the weave patterns of hemp fibers have a considerable effect on the moisture absorption and porosity of the hemp fiber-based composite. The most efficient form of the hemp composite in terms of costs and material aspects is the woven preforms. For the hemp/PLA composite, the non-woven hemp fiber-reinforced PLA composite exhibits the highest moisture absorption. The hemp woven fabric-reinforced PLA composite has a higher compact and close packing of hemp/PLA relative to the non-woven hemp/PLA composite. This packing structure mitigates the porosity inside the composite structure, which participates in reducing the moisture absorption $[218,219]$. The most critical feature for the effective use of natural fibers such as hemp fibers in natural composites is the optimal interfacial adhesion between the hydrophobic resin and hydrophilic fibers [83]. The optimum adhesion at the fiber-matrix interface can be achieved through using chemical and physical treatment methods [119]. The alkali treatment of hemp fibers removes a specific amount of wax, lignin, oil, pectin, and hemicellulose, transforming some amount of alpha to beta cellulose, increasing the roughness of the fiber surface, and improving the water uptake properties of the treated composite. Treating hemp fibers with alkali and silane treatments increases the interfacial adhesion strength in hemp/polyurethane, which prevents water molecules from penetrating in the interfacial region [83,220-222]. The moisture content of the hemp fiber-based composite is increased with increasing fiber loading and when the diameter of the hemp fiber is reduced. This behavior can be attributed to the improved fiber surface area at lower diameters, leading to a higher availability of the polar-OH group in the resin-fiber system $[156,223,224]$. For example, the increasing content of hemp fibers in unsaturated polymer resin induces the composite to absorb a higher amount of moisture, leading to a great reduction of the tensile and flexural properties of the composite [225]. This reduction is attributed to the considerable degradation of the interfacial strength of the hemp/polymer region after exposure to moisture aging [226,227]. The type of hosting matrix - whether it is composed of synthetic or biopolymer resin-has a considerable effect on the interfacial adhesion in the hemp/epoxy composite. It is noticed that hemp fibers have a poor interfacial 
bond strength with fully synthetic epoxy resin, while they have a good interfacial bond strength with green epoxy resin [228].

\section{The Effect of Fiber Loading}

The water uptake, diffusivity, and the resulting thickness swelling are increased with the increasing content of fibers in natural composites, which leads to an acceleration of the biodegradation rate of the composite [229-231]. Composite structures with higher thicknesses have a higher capability to absorb moisture relative to thinner ones. Consequently, an optimum fiber loading should be selected to attain balance in all aspects of composites, including mechanical properties [232]. Referring to Figure 9, the fiber content along with water immersion time play a key role in controlling the quantity of moisture absorbed by natural composites. For instance, epoxy composites reinforced with around $20 \mathrm{wt}$ \% and $46 \mathrm{wt}$. \% of recycled cellulose fiber that is immersed in distilled water for $5616 \mathrm{~h}$ exhibit the highest amount of moisture absorption. This behavior is attributed to the two main factors of the high cellulosic content in natural composite, and the long immersing duration of the composite in distilled water.

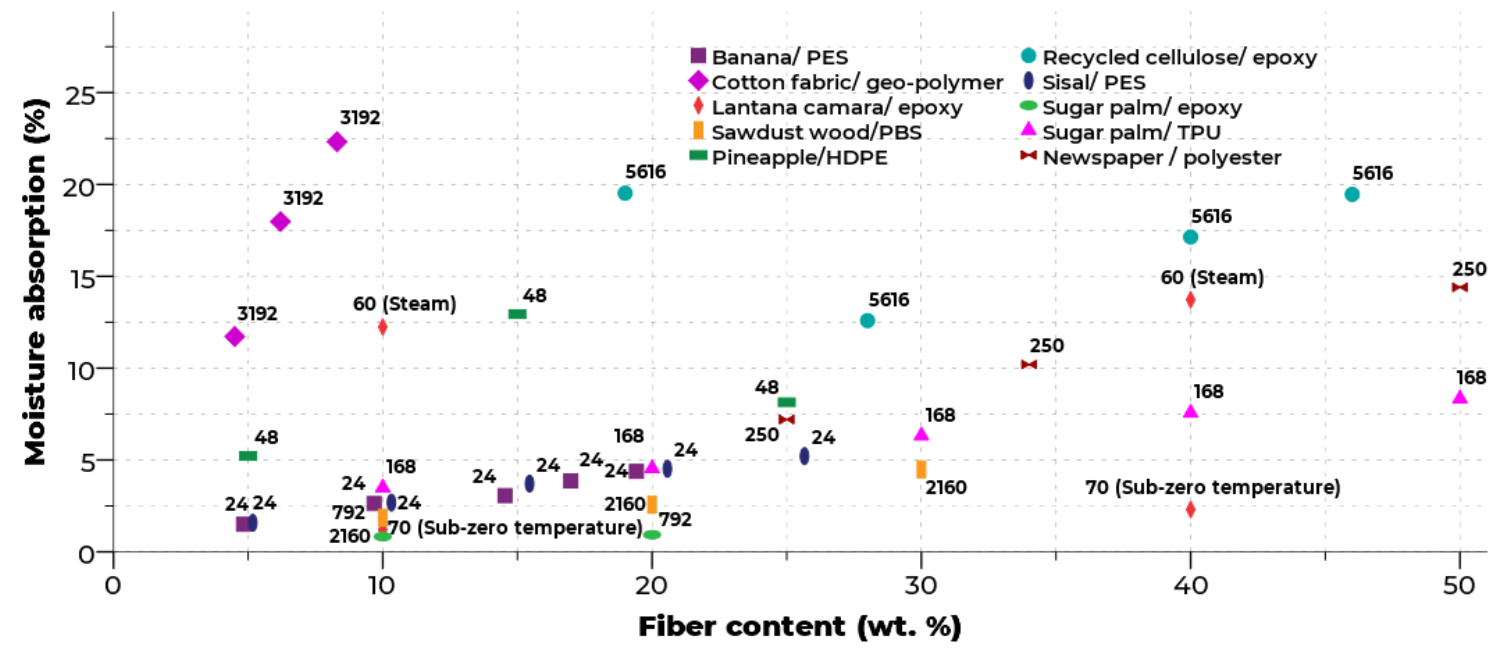

Figure 9. The effect of fiber loading and immersion time (shown in the above data points) on the percentage of moisture absorbed by natural composites. Banana fiber/polyester [74], CF/geopolymer [28], Lantana camara fiber/epoxy [68], Padauk sawdust wood/ biodegradable PBS [157], Pineapple fiber/HDPE [155], RCF/epoxy [154], Sisal/PES [232], SPF/epoxy [76], SPF/TPU [158], Unshredded waste newspaper/PES [233].

This conclusion can be further verified through investigating the moisture absorption behavior of cotton fabric-reinforced geopolymer composites. The long immersing duration of the composite in distilled water $(3192 \mathrm{~h}$ ) induces the composite to absorb around $18 \%$ of the moisture from the conditioning medium, even though the composite is reinforced with less than $8 \mathrm{wt}$. \% of cotton fabric. Reinforcing natural composites with higher loadings of natural fibers is a desirable optimization objective, since the natural fibers improve the overall mechanical properties of natural composites. A trade-off can be achieved between the loading of natural fibers and the moisture absorption behavior of natural composites through hybridizing the composite structure with other natural and/or synthetic fibers characterized by a lower tendency to absorb moisture. More details about the hybridization of natural composites will be provided in Section 6 .

\section{Hybridization of Natural Composites}

Based on the non-renewable/renewable source of resin/fiber, the polymeric composites can be divided into three main types: (i) synthetic polymeric composites; (ii) entire renewable (green) polymeric composites; (iii) partially renewable composites [15]. The hybrid composite can be fabricated 
through the combination of two types of different fibers, which are used to reinforce the common hosting matrix. The hybridization of the natural composite is considered to be an effective method to reduce the moisture absorption [234]. The effect of hybridization on the moisture absorption behavior for both entire and partially natural hybrid composites can be better realized through exploring the moisture improvement values listed in Table 3, which are calculated relative to unhybridized composites. It can be noted that the hybridization of natural composites has an adverse impact on the coefficient of water diffusion due to the increasing load of voids in the composite structure and poor interfacial adhesion between the laminates of hybrid composites.

Table 3. The effect of hybridizing natural fibers on moisture absorption properties.

\begin{tabular}{|c|c|c|c|c|}
\hline References & Hybrid Composite & $\begin{array}{c}\text { Moisture } \\
\text { Improvement \% }\end{array}$ & $\begin{array}{c}\text { Diffusivity } \\
\text { Improvement \% }\end{array}$ & $\begin{array}{c}\text { Immersion Time } \\
\text { (Hours) }\end{array}$ \\
\hline [235] & $\begin{array}{l}\text { Sisal fibers hybridized banana at } \\
\text { (50:50) reinforced epoxy. }\end{array}$ & 11.48 & -12.13 & 50 \\
\hline [87] & $\begin{array}{l}7 \text { wt. \% Glass hybridized } 13 \text { wt. \% } \\
\text { coir-reinforced polyester. }\end{array}$ & 39.16 & - & 1440 \\
\hline [236] & $\begin{array}{l}\text { 15\% Glass fibers hybridized 15\% } \\
\text { jute-reinforced 70\% UP. }\end{array}$ & 58.36 & -309.79 & 504 \\
\hline \multirow{3}{*}{ [237] } & $\begin{array}{l}5 \text { wt. \% Glass hybridized } 35 \text { wt. \% } \\
\text { hemp-reinforced } 55 \text { wt. \% PP. }\end{array}$ & 6.76 & - & \multirow{3}{*}{3600} \\
\hline & $\begin{array}{l}10 \text { wt. \% Glass hybridized } 30 \text { wt. \% } \\
\text { hemp-reinforced } 55 \text { wt. \% PP. }\end{array}$ & 21.31 & - & \\
\hline & $\begin{array}{l}15 \text { wt. \% Glass hybridized } 25 \text { wt. \% } \\
\text { hemp-reinforced } 55 \text { wt. \% PP. }\end{array}$ & 37.11 & - & \\
\hline
\end{tabular}

In this section, the entire and partially natural hybrid composites are discussed with further details through Sections 6.1 and 6.2, respectively.

\subsection{Entire Natural Hybrid Composites}

The hybridization improves the dynamic mechanical properties, including the loss and storage moduli, and reduces the moisture absorption capabilities of natural composite [238-240]. The fully natural hybrid composites find different applications in the construction and industrial sectors. Green biocomposites are developed through gluing hemp shiv with wheat straw. The developed composite exhibits hygric and thermal performances which contribute to mitigate the energy demands of building and guarantee the hygrothermal comfort of users [241,242]. Using natural fibers characterized with relatively high impedance against moisture absorption is one of the options to improve the water uptake behavior of natural fiber composites. Mineral fibers such as basalt fibers are frequently used to hybridize natural composites in order to improve their moisture resistance and durability, in addition to their mechanical properties. Usually, basalt fiber-based composites are used to fabricate the skin laminates of the hybrid sandwich composites in order to protect the natural fibers with lower moisture resistance, such as flax and hemp fibers, from absorbing the moisture found in the surrounding environment [243-246]. The basalt fibers enhance the interfacial adhesion, mitigating the moisture absorption, and consequently postponing the structural degradation of basalt/flax hybrid laminated composites. The moisture absorption changes the failure mechanism of flax-basalt hybrid composites, as demonstrated in Figure 10, due to the plasticization phenomena. Furthermore, the moisture absorption induces the delamination between basalt layers and interior flax-based layers [247]. Structural flaws such as delamination, matrix cracking, and voids increase the capability of hybrid composites to absorb moisture and mitigate the strength of the moisture-saturated composite due to the degradation of the interface between the matrix and fiber [248]. The most critical factor that promotes the structural failure in hybrid composites is the content of porosity and air voids. It is recommended to dry the natural fibers through the fabrication process before resin injection in order attain fibers characterized with good wetting properties as well as prevent any generation of gas bubbles during curing $[249,250]$. 


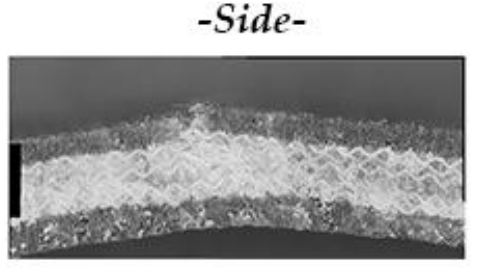

Flax-basalt (Raw)

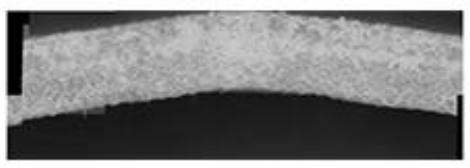

Flax core

(a)

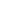
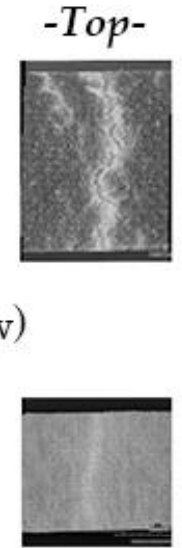

\begin{abstract}
(2)
\end{abstract}

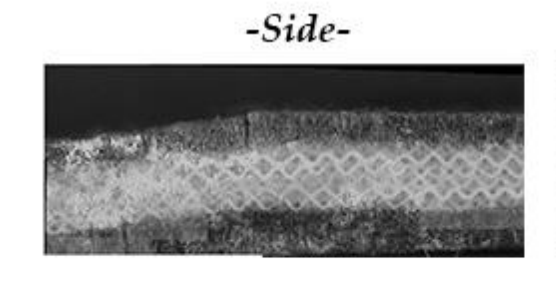

Flax-basalt (Aged)

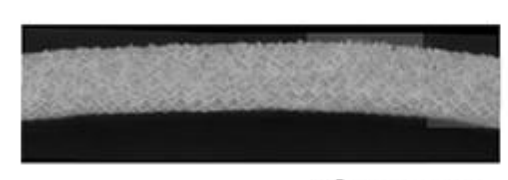

Flax core
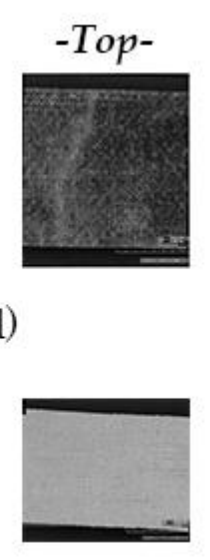

(b)

Figure 10. The variation between (a) raw and (b) 60-day aged basalt/flax hybrid composite in terms of failure mode. Reproduced with permission from [247].

A superior moisture absorption improving effect can be attained through using chemical/physical treatments associated with hybridization. Poplar wood flour and recycled newspaper fiber are combined in the recycled PP matrix modified with MAPP. This composite includes a higher fraction of recycled newspaper fiber, which shows maximum moisture absorption due to the presence of a high quantity of holocellulose. The incorporation of MAPP has an advantageous influence on both the thickness swelling and moisture absorption through enhancing the quality of adhesion between the fibers and polymer [251].

\subsection{Partially Natural Hybrid Composites}

Hybridizing natural fibers with synthetic ones such as glass or carbon fibers is an efficient technique that is used for controlling the vibration damping and enhancing the mechanical and moisture absorption properties of partially natural hybrid composites [252]. The incorporation of natural fibers such as jute and flax fibers to carbon and glass fiber-based composites improves the flexural properties, ductility, and impact strength of the hybrid composites, while the carbon and glass fibers participate in enhancing the moisture absorption behavior, stiffness, strength, and thermal stability of the hybrid composites [253-257]. Glass fiber is considered an economically feasible fiber characterized with high tensile strength, low moisture absorption capability, and high dimensional stability. Glass fiber-based composites have a good capability to resist various weathering conditions, including exposure to moisture and heat aging conditions [209,258-262]. For instance, the amounts of moisture absorption for the kenaf/VE composite are $97.95 \%$ and $98.35 \%$ higher than that of the glass/VE composite under tensile and flexural loading conditions, respectively. Likewise, the saturated weight gain of flax fiber composites is 12 -fold higher than that of glass fiber composites. Additionally, the incorporation of two external glass fiber layers considerably improves the moisture absorption of the glass/flax hybrid composite by more than $180 \%$ compared to the flax/epoxy composite. Therefore, the increasing content of synthetic hydrophobic fiber in hybrid natural composite mitigates the content and absorption speed of moisture [258,263-271]. Glass fibers can be used to improve the moisture absorption properties of natural sandwich composite structures [272]. Skin layers of woven jute fabric are used to cover the particleboards' core composite, which is composed of a mixture of short glass fibers and wood particles. The hybrid composite shows good dimensional stability and outstanding moisture resistance relative to commercially available wood-based composites [273].

Using a coupling agent such as MAPP adds further improvement to the tensile strength and moisture absorption behavior of hybrid composites [274]. The hybrid composite of glass/bamboo 
fibers reinforced with PP and modified with MAPP is immersed in water for $1200 \mathrm{~h}$ at $25^{\circ} \mathrm{C}$. Due to the hybridization with glass fibers, a reduction in moisture absorption of $4 \%$ relative to unhybridized composite has been recorded [275]. The synthetic fibers can be organized in a randomly close-packed structure in order to prevent the water molecules from diffusing inside the composite structure, and hence hinder them from contacting and binding with the surfaces of hydrophilic natural fibers [87]. When the water molecules diffuse into a hybrid composite, composite failure takes place due to the jute fiber swelling, which creates swelling stresses leading to the failure of the composite. The moisture absorption weakens the interfacial bonding strength between the fiber and matrix, reduces the stiffness of the natural fiber, leads to the stress corrosion of synthetic fibers, and plasticizes the polymeric matrix [276]. For example, the water penetration into woven glass/long kenaf degrades the fracture toughness due to the weakening of the interfacial bond strength between the fiber and polymer [277]. A glass and twill flax fiber-reinforced epoxy hybrid composite is immersed in water at $55{ }^{\circ} \mathrm{C}$. Delamination between the glass and flax fiber-based layers is initiated due the moisture absorption. This leads to a reduction in the maximum tensile strength of the moisture saturated composite [278]. On the contrary, it is demonstrated that in some cases, the molecules of water that penetrate into the cracks and cavities within the composite structure increase the flexibility of the hybrid composite [279].

\section{Incorporation of Nanofillers}

Nanotechnology can be implemented to improve the moisture absorption properties of natural fibers composites through using nanofillers and nanotechnology-based coatings. The particle forms of some types of natural fibers can add considerable improvement to the water uptake behavior of natural composites relative to other forms of mats and short fibers [280-282]. Polyethyleneimine-reduced graphene oxide fillers can be used to improve the tortuous diffusion pathway for water molecules and the surface hydrophobicity of methyl cellulose composite films, which can be used in water vapor barrier application [283]. The nanofillers such as fly ash particles function as additive and reinforcing fillers, filling the air gaps and voids that exist in the structure of sustainable composites [284]. The incorporation of metal oxide particles into the structure of natural composites improves their moisture absorption and swelling properties. This behavior is attributed to the good capability of hydrophobic metal oxides to bond with hydrophobic polymers [285]. Reinforcing kenaf fibers composites with magnetite particles offers dual-functional properties such as paramagnetic and electromagnetic shielding functions in addition to moisture absorption resistance [286]. $\mathrm{TiO}_{2}$ fillers can be used to enhance the water uptake behavior for natural and synthetic fiber-based composites. Incorporating $0.1 \mathrm{wt}$. \% of $\mathrm{TiO}_{2}$ filler into glass fiber-reinforced polymer composite decreases the diffusivity by $9 \%$ [287]. Furthermore, $18 \%$ of water sorption reduction can be achieved upon the grafting of $\mathrm{TiO}_{2}$ particles on the surface of flax fibers that are used to embed PLA composites. An oxidization treatment is carried out on the surface of flax fiber in order to enhance the interfacial adhesion of $\mathrm{TiO}_{2}$ film to flax fibers, as shown in Figure 11. This enhanced adhesion prevents the penetration of water molecules and propagation of cracks in the interphase region [288,289]. Likewise, the incorporation of $\mathrm{SiC}$ nanoparticles into cellulose fiber-reinforced epoxy strengthens the interfacial adhesion between the fiber and matrix [48]. Carbon nanotubes (CNTs) are used to lower the moisture absorption tendency of wood filler-reinforced HDPE. With the increasing content of CNTs, the equilibrium time (the time needed to attain the equilibrium thickness swelling) and thickness swelling are reduced. This reduction is attributed to the barrier properties of CNTs, which hinder the water diffusion into the composite structure. CNTs can inhibit the moisture penetration into the composite through two main mechanisms: (i) CNTs hinder the diffusion of water into deeper regions of the composite through filling the air gaps and voids; (ii) the surface of CNTs tends to immobilize the amount of the moisture due to its hydrophobic nature [290,291]. The effect of natural nanofillers such as cellulose and clay reinforcements on the moisture absorption behavior of natural composites is further investigated through Sections 7.1 and 7.2, respectively. 


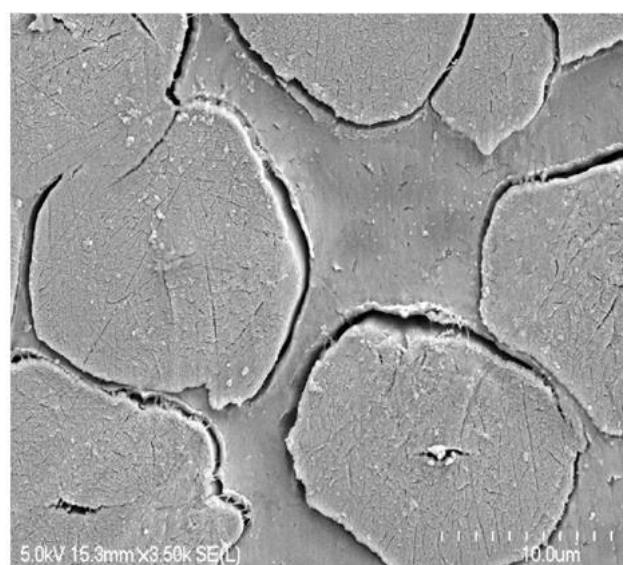

(a)

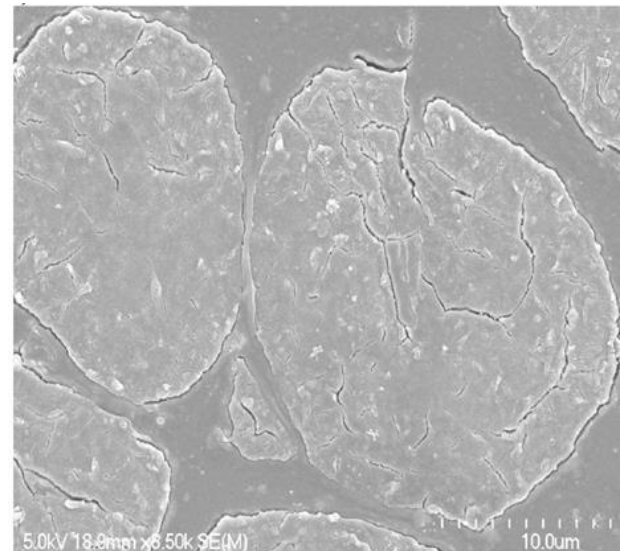

(b)

Figure 11. Cross-sectional area for (a) raw, (b) Oxidized- $\mathrm{TiO}_{2}$ interphase modified flax fiber-reinforced composites. Reproduced with permission from [288].

\subsection{Cellulosic Reinforcements}

CNCs and cellulose nanofibers are natural particles characterized by a high surface area and high strength. The cellulose nanofillers can be extracted from natural fibers such as sisal fibers without considerable quantities of lignin and hemicellulose. The implementation of CNCs is being investigated for different uses, since it is stiffer than aluminum and stronger than steel. CNCs may be used to manufacture multi-scale composites with advanced mechanical performance, long service life, and good durability at different weathering conditions. Hence, crystalline and viscous CNCs can be implemented to manufacture high performance cement nanocomposites that have an increased tortuosity, which hinders the diffusion of water into the composite structure $[153,169,292]$. CNCs can be used to mitigate the water sensitivity of starch/poly vinyl alcohol composite films. This moisture stability originates from the creation of strong hydrogen bonds among the hydroxyl groups from constitutes of the film through a three-dimensional network. With an increasing loading of starch, the water sorption of the film is reduced further [293]. The moisture behavior and tensile properties of starch-based composites can be improved through incorporating bacterial cellulose (BC) nanofibers in the composite structure. Both $\mathrm{BC}$ and starch are hydrophilic in nature, which could render the high moisture absorption of the composite. The higher resistance toward moisture absorption for $\mathrm{BC} / \mathrm{starch}$ composites relative to a pure starch matrix is attributed to the strong hydrogen bonding created at the matrix-fiber interface and to the higher resistance of BC nanofibers to weathering conditions [294].

\subsection{Clay Nanoparticles}

Nanofillers such as nanoclay and nano silica carbide can be incorporated into natural fiber-based composites in order to improve their water uptake behavior through improving their mechanical properties in wet conditions. The clay nanolayer forms an impermeable medium to hinder the flow of water and force the water to flow through an indirect path, and consequently, a longer time is needed for water diffusion [295]. In addition to natural composites, clay nanoparticles can be used to improve the moisture absorption properties of synthetic fiber-based composites. Small amounts of silane coupling agents are usually needed to treat nanoclays in order to produce nanocomposites characterized with higher resistance to hygrothermal aging conditions, along with the better retention of flexural and tensile strength properties. The enhancing effect of silane coupling agents can be attributed to the influence of salinization on exfoliation, as well as creating covalent bonds with the hosting matrix [296]. A glass fiber-reinforced VE composite has been modified with $1.0 \mathrm{wt}$ \% of raw and (3-Aminopropyl)triethoxysilane (APTES)-treated montmorillonite (MMT) nanoclay. When the nanoclay comes into contact with moisture, swelling among layers takes place, which as a result changes the mechanical properties of the resulting composite. A composite reinforced with 
silane-treated MMT exhibits better mechanical properties after immersion in sea water due to the improved interfacial adhesion at the MMT-VE interface [297]. Nanoclays alleviate the reduction that occurs in the mechanical properties of carbon fiber-reinforced polymers after exposure to sea water, and improve the impedance of the composites toward moisture absorption. A composite in which $2.0 \%$ nanoclays are dispersed in its matrix absorbed $0.39 \%$ of sea water, while the control composite absorbed $0.67 \%$ of water. This improvement can be justified to the outstanding barrier capacity along with the high aspect ratio and surface area of clay nanofillers [298]. Organoclay is another type of clay nanofillers that can significantly improve the water uptake behavior of natural composites. The effectiveness of organoclays on moisture absorption reduction depends on many factors, such as the polarity of organic moieties and the morphology of nanoclays in the hosting resin [296]. Organoclays (ammonia salts) are used to fabricate poly vinyl alcohol/functional clay aerogel composites. Depending on the RH, a five-fold reduction can be achieved for composites reinforced with organoclay relative to those reinforced with traditional clays. The main outcome of the aforementioned study shows that the moisture sorption capacity is mitigated by up to $40 \%$ after 30 days of aging under a RH of $85 \%$ due to the increase in the interlayer space, which forms a more tortuous path for heat to pass through [299].

\section{Conclusions}

This review demonstrates through previously published experimental data that treating natural composites with chemical and/or physical treatments alone does not provide the treated composites with adequate resistance toward moisture absorption. Actually, there are a number of parameters that govern the efficiency of the chemical or physical treatment method on improving the moisture absorption behavior of natural composites, including: the proper selection of the hosting matrix and natural fiber, adjusting the fiber loading and duration of the moisture exposure with applied moisture treatment, the hybridization with hydrophobic and minerals fibers, and lastly, the implementation of natural and synthetic nanofillers. A complete comparison between the aforementioned parameters in terms of their capability on improving the moisture absorption behavior of natural composites is discussed in Table 4. Choosing an appropriate type of natural fiber and hosting matrix considerably affects the efficiency of the treatment applied on natural composites. The compatibility between hosting resin and reinforcing fiber is a very critical parameter that determines the degree of bond strength at the fiber-matrix interface. The loading of the natural fiber and the aging time are directly correlated to each other. Increasing the fiber content and aging duration induces the natural composites to absorb higher quantities of moisture from the conditioning medium, regardless of the applied chemical and/or physical treatments. The hybridization of natural fibers with synthetic fibers reduces the amount of moisture treatments that are needed, which can be specified through the loading ratio of synthetic to natural fibers. For example, if the hybridization is done at a 50:50 ratio, the amount of treatment that is needed is decreased by $50 \%$. This can be attributed to the capability of hybridizing fibers to form excellent interfacial adhesion with the synthetic hosting resin, which prevents the water molecules from passing to the interior hydrophilic natural fibers. It is noteworthy to highlight the adverse impact of hybridizing natural composites on reducing the efficiency of moisture absorption treatments, since the hybridization increases the coefficient of water diffusion inside the composite structure. This can be attributed to the voids and gaps that exist in the structure of the hybrid composite in addition to the poor interfacial adhesion between the laminates of different reinforcing fibers. The role of secondary nanofillers is magical when these fillers are used along with chemical/physical treatments, since these fillers perform multiple tasks at the interface, including: (a) strengthening the mechanical interlocking through increasing the surface roughness of the natural fibers, (b) alleviating the damaging effect of delamination emerged from moisture absorption through the pinning mechanism, (c) improving the overall barrier properties of natural composites through offering additional tortuous paths to composite structure that decelerate the penetration of water molecules, and (d) eliminating the air gaps and voids generated due to the poor compatibility between the hydrophilic natural fiber and hydrophobic hosting resin through filling them. 
Table 4. Comparison between moisture treatment parameters of natural composites.

\begin{tabular}{|c|c|c|c|c|c|c|}
\hline No. & $\begin{array}{l}\text { Treatment } \\
\text { Parameter }\end{array}$ & Moisture Resistance & Moisture Diffusivity & Interfacial Adhesion & Efficiency of Treatment & Void Content \\
\hline 1. & $\begin{array}{l}\text { Type of hosting } \\
\text { matrix }\end{array}$ & $\begin{array}{l}\text { Hydrophobic synthetic resins } \\
\text { provide protection for the } \\
\text { hydrophilic natural fiber regardless } \\
\text { of fiber type. Consequently, } \\
\text { choosing an appropriate type of } \\
\text { resin is more important relative to } \\
\text { the type of natural fiber. }\end{array}$ & $\begin{array}{l}\text { Heavy chemical/physical } \\
\text { treatments are not needed, } \\
\text { since the hydrophobic } \\
\text { polymers deaccelerates the } \\
\text { diffusion of water molecules. }\end{array}$ & $\begin{array}{l}\text { Interfacial adhesion is weak } \\
\text { due to poor covalent bonding } \\
\text { between the hydrophobic and } \\
\text { hydrophilic components. }\end{array}$ & $\begin{array}{l}\text { The incorporation of MA in the } \\
\text { hydrophobic resin increases the } \\
\text { capability of most polymers to } \\
\text { resist moisture. }\end{array}$ & $\begin{array}{l}\text { The thermoset resins such as epoxy } \\
\text { contain a specific loading of voids, } \\
\text { which facilitates the penetration of } \\
\text { water molecules. Thermoplastic } \\
\text { polymers such as PP are highly } \\
\text { recommended for natural composite } \\
\text { applications. }\end{array}$ \\
\hline 2. & $\begin{array}{l}\text { Type of natural } \\
\text { fiber }\end{array}$ & $\begin{array}{l}\text { It is recommended to use natural } \\
\text { fibers with a higher degree of } \\
\text { compatibility with hydrophobic } \\
\text { resins in order to improve the } \\
\text { moisture absorption properties. The } \\
\text { overtreatment of natural fibers } \\
\text { should be avoided. }\end{array}$ & $\begin{array}{l}\text { The packing arrangement of } \\
\text { natural fibers play a key role in } \\
\text { reducing the water diffusivity. } \\
\text { The woven arrangement of } \\
\text { natural fibers is recommended. }\end{array}$ & $\begin{array}{l}\text { The type of natural fiber has } \\
\text { the highest impact on the } \\
\text { interfacial adhesion's bond } \\
\text { strength. Natural fibers with } \\
\text { higher surface areas and aspect } \\
\text { ratios induce composites to } \\
\text { absorb moisture at the } \\
\text { fiber-matrix interface. }\end{array}$ & $\begin{array}{l}\text { The type of natural fiber controls } \\
\text { the success of the } \\
\text { chemical/physical treatment } \\
\text { process. Treating specific types of } \\
\text { fibers makes them more exposed to } \\
\text { moisture due to the } \\
\text { over-elimination of extractive } \\
\text { elements such as lignin from the } \\
\text { fiber structure. }\end{array}$ & $\begin{array}{l}\text { The moisture treatments increase the } \\
\text { surface roughness of natural fibers, } \\
\text { which improves the fiber wetting in } \\
\text { the hosting resin, leading to a } \\
\text { considerable reduction in the void } \\
\text { content at the fiber-matrix } \\
\text { interphase region. }\end{array}$ \\
\hline 3. & Fiber loading & $\begin{array}{l}\text { The fiber loading reduces the } \\
\text { moisture absorption behavior of the } \\
\text { natural composite. With the } \\
\text { increasing content of cellulose in the } \\
\text { natural composite, the application of } \\
\text { efficient chemical/physical } \\
\text { treatments is recommended. }\end{array}$ & $\begin{array}{l}\text { Applying a polymeric coating } \\
\text { on natural composites that is } \\
\text { reinforced with higher } \\
\text { loadings of natural fiber is an } \\
\text { essential requirement for } \\
\text { reducing the moisture } \\
\text { diffusion due to the increasing } \\
\text { content of air voids at the } \\
\text { fiber-matrix interface. }\end{array}$ & $\begin{array}{l}\text { Applying chemical/physical } \\
\text { treatments for improving the } \\
\text { interfacial adhesion is of } \\
\text { primary importance at higher } \\
\text { loadings of natural fibers. }\end{array}$ & $\begin{array}{l}\text { The efficiency of moisture } \\
\text { treatments is limited at higher } \\
\text { contents of natural fibers, and using } \\
\text { another parameter for moisture } \\
\text { behavior improvement such as } \\
\text { hybridizing composites with } \\
\text { synthetic/mineral fibers is } \\
\text { recommended. }\end{array}$ & $\begin{array}{l}\text { With increasing fiber content, the } \\
\text { void loading is increased due to poor } \\
\text { interfacial adhesion, which induces } \\
\text { the composite to absorb higher } \\
\text { amounts of moisture. Improving the } \\
\text { bond strength is required through } \\
\text { applying chemical/physical } \\
\text { treatments. }\end{array}$ \\
\hline 4. & $\begin{array}{l}\text { Hybridization } \\
\text { of natural fiber }\end{array}$ & $\begin{array}{l}\text { The hybridization alleviates the need } \\
\text { for chemical/physical treatments if } \\
\text { proper synthetic or mineral fibers are } \\
\text { used to cover the external layers of } \\
\text { natural composites. The moisture } \\
\text { absorption resistance is improved } \\
\text { with the increasing content of } \\
\text { synthetic/mineral fibers. }\end{array}$ & $\begin{array}{l}\text { The diffusivity can be } \\
\text { improved with minimal } \\
\text { chemical/physical treating } \\
\text { efforts if the external layers of } \\
\text { synthetic/mineral fibers } \\
\text { prevent the water molecules } \\
\text { from penetrating into the } \\
\text { interior composite's core. }\end{array}$ & $\begin{array}{l}\text { The improvement attained on } \\
\text { interfacial adhesion is } \\
\text { proportional to the loading of } \\
\text { synthetic/mineral fibers used } \\
\text { due to the capability of these } \\
\text { fibers to form strong covalent } \\
\text { bonding with the hosting } \\
\text { matrix. }\end{array}$ & $\begin{array}{l}\text { The hybridization enhances the } \\
\text { efficiency of moisture treatments } \\
\text { applied on natural composites, } \\
\text { since the layers of } \\
\text { synthetic/mineral fibers do not } \\
\text { need additional treatments. }\end{array}$ & $\begin{array}{l}\text { The void content is greatly reduced } \\
\text { with the increased loading of } \\
\text { synthetic/mineral fibers in the } \\
\text { composite structure due to the good } \\
\text { wetting capability of these fibers } \\
\text { with the hosting matrix. }\end{array}$ \\
\hline 5. & $\begin{array}{l}\text { Implementation } \\
\text { of nanofillers }\end{array}$ & $\begin{array}{l}\text { Nanofillers improve the moisture } \\
\text { barrier properties of composites. It } \\
\text { should be considered as a second } \\
\text { option in hand after choosing a } \\
\text { suitable type of natural fiber. }\end{array}$ & $\begin{array}{l}\text { Nanoreinforcements can } \\
\text { effectively reduce the water } \\
\text { diffusivity through the } \\
\text { additional tortuous paths that } \\
\text { are created in the composite } \\
\text { structure. }\end{array}$ & $\begin{array}{l}\text { They can be used to reduce the } \\
\text { degree of incompatibility at the } \\
\text { fiber-matrix interface through } \\
\text { their pinning mechanism, } \\
\text { regardless of the fiber and } \\
\text { matrix types. }\end{array}$ & $\begin{array}{l}\text { Nanofillers need additional } \\
\text { chemical/physical treatments } \\
\text { beside moisture treatments for } \\
\text { improving their adhesion at the } \\
\text { surface of the natural fiber. }\end{array}$ & $\begin{array}{l}\text { They considerably reduce the voids' } \\
\text { content through their key role of } \\
\text { filling these voids without applying } \\
\text { additional treatments for improving } \\
\text { the interfacial adhesion at } \\
\text { fiber-matrix region. }\end{array}$ \\
\hline
\end{tabular}


Author Contributions: Writing—original draft preparation, A.Y.A.-M.; writing—review and editing, A.Y.A.-M. and N.A.-H.; supervision, N.A.-H.

Funding: This research received no external funding.

Conflicts of Interest: The authors declare no conflict of interest.

Nomenclature

\begin{tabular}{|c|c|}
\hline AA & Acrylic acid \\
\hline AN & Acrylonitrile \\
\hline APTES & 3-aminopropyltriethoxy silane \\
\hline APTMOS & Aminopropyltrimethoxy silane \\
\hline AS & (3-aminopropyl)-triethoxysilane \\
\hline $\mathrm{BC}$ & Bacterial cellulose \\
\hline CNCs & Cellulose nanocrystals \\
\hline CNTs & Carbon nanotubes \\
\hline GLYMO & y-glycidoxypropyltrimethoxysilane \\
\hline GPS & 3-glycidoxypropyltrimethoxysilane \\
\hline HDPE & High-density polyethylene \\
\hline HDS & Hexadecyltrimethoxy-silanes \\
\hline LDPE & Low density polyethylene \\
\hline MA & Maleic anhydride \\
\hline MAPP & Maleic anhydride grafted polypropylene \\
\hline MMT & Montmorillonite \\
\hline MPS & c-methacryloxypropyltrimethoxy silane \\
\hline MRPS & c-mercaptoproyltrimethoxy silane \\
\hline MS & 3-(trimethoxysilyl)-1-propanethiol \\
\hline NDS & Natural digestion system \\
\hline OPEFB & Oil palm empty fruit bunch \\
\hline OTMOS & n-Octyltrimethoxy silane \\
\hline OSF & Olive stone flour \\
\hline PBS & Poly (butylene succinate) \\
\hline PE & Polyethylene \\
\hline PES & Polyester \\
\hline PLA & Poly lactic acid \\
\hline PP & Polypropylene \\
\hline $\mathrm{RH}$ & Relative humidity \\
\hline SEBS & Styrene ethylene butadiene styrene-grafted maleic anhydride \\
\hline TESPTS & Bis (3-(triethoxysily) Propyl) tetrasulphide \\
\hline TEVS & triethoxy vinyl silane \\
\hline TMSPMA & 3-trimethoxysilyl propyl methacrylate \\
\hline TPU & Thermoplastic polyurethane \\
\hline UP & Unsaturated polyester \\
\hline VE & Vinyl ester \\
\hline VG & Vinyl grafting \\
\hline VTMOEO & Vinyltris (2-methoxyethoxy) silane \\
\hline VTMS & Vinyltrimethoxy silane \\
\hline WF & Wood flour \\
\hline WPCs & Wood plastic composites \\
\hline
\end{tabular}

\section{References}

1. Zhou, B.; Shi, J.; Qian Chen, Z. Experimental study on moisture migration process of zeolite-based composite humidity control material. Appl. Therm. Eng. 2018, 128, 604-613. [CrossRef] 
2. Belakroum, R.; Gherfi, A.; Bouchema, K.; Gharbi, A.; Kerboua, Y.; Kadja, M.; Maalouf, C.; Mai, T.; El Wakil, N.; Lachi, M. Hygric buffer and acoustic absorption of new building insulation materials based on date palm fibers. J. Build. Eng. 2017, 12, 132-139. [CrossRef]

3. Yan, L.; Chouw, N.; Jayaraman, K. Effect of UV and water spraying on the mechanical properties of flax fabric reinforced polymer composites used for civil engineering applications. Mater. Des. 2015, 71, 17-25. [CrossRef]

4. Yan, L.; Chouw, N. Effect of water, seawater and alkaline solution ageing on mechanical properties of flax fabric/epoxy composites used for civil engineering applications. Constr. Build. Mater. 2015, 99, 118-127. [CrossRef]

5. Cheour, K.; Assarar, M.; Scida, D.; Ayad, R.; Gong, X.-L. Effect of water ageing on the mechanical and damping properties of flax-fibre reinforced composite materials. Compos. Struct. 2016, 152, 259-266. [CrossRef]

6. Dunne, R.; Desai, D.; Sadiku, R. Material characterization of blended sisal-kenaf composites with an ABS matrix. Appl. Acoust. 2017, 125, 184-193. [CrossRef]

7. Putra, A.; Or, K.H.; Selamat, M.Z.; Nor, M.J.M.; Hassan, M.H.; Prasetiyo, I. Sound absorption of extracted pineapple-leaf fibres. Appl. Acoust. 2018, 136, 9-15. [CrossRef]

8. Kong, C.; Lee, H.; Park, H. Design and manufacturing of automobile hood using natural composite structure. Compos. Part B Eng. 2016, 91, 18-26. [CrossRef]

9. Malkapuram, R.; Kumar, V.; Negi, Y.S. Recent development in natural fiber reinforced polypropylene composites. J. Reinf. Plast. Compos. 2009, 28, 1169-1189. [CrossRef]

10. Elanchezhian, C.; Ramnath, B.V.; Ramakrishnan, G.; Rajendrakumar, M.; Naveenkumar, V.; Saravanakumar, M. Review on mechanical properties of natural fiber composites. Mater. Today Proc. 2018, 5, 1785-1790. [CrossRef]

11. Célino, A.; Gonçalves, O.; Jacquemin, F.; Fréour, S. Qualitative and quantitative assessment of water sorption in natural fibres using ATR-FTIR spectroscopy. Carbohydr. Polym. 2014, 101, 163-170. [CrossRef] [PubMed]

12. Gassan, J.; Bledzki, A. Possibilities to improve the properties of natural fiber reinforced plastics by fiber modification-Jute polypropylene composites. Appl. Compos. Mater. 2000, 7, 373-385. [CrossRef]

13. Lau, K.-T.; Hung, P.-Y.; Zhu, M.-H.; Hui, D. Properties of natural fibre composites for structural engineering applications. Compos. Part B Eng. 2018, 136, 222-233. [CrossRef]

14. Fernandes, R.; De Moura, M.; Moreira, R. Effect of moisture on pure mode I and II fracture behaviour of composite bonded joints. Int. J. Adhes. Adhes. 2016, 68, 30-38. [CrossRef]

15. Thakur, V.K.; Thakur, M.K. Processing and characterization of natural cellulose fibers/thermoset polymer composites. Carbohydr. Polym. 2014, 109, 102-117. [CrossRef]

16. Kabir, M.M.; Wang, H.; Lau, K.T.; Cardona, F. Chemical treatments on plant-based natural fibre reinforced polymer composites: An overview. Compos. Part B Eng. 2012, 43, 2883-2892. [CrossRef]

17. Van de Weyenberg, I.; Truong, T.C.; Vangrimde, B.; Verpoest, I. Improving the properties of UD flax fibre reinforced composites by applying an alkaline fibre treatment. Compos. Part A Appl. Sci. Manuf. 2006, 37, 1368-1376. [CrossRef]

18. Azwa, Z.; Yousif, B.; Manalo, A.; Karunasena, W. A review on the degradability of polymeric composites based on natural fibres. Mater. Des. 2013, 47, 424-442. [CrossRef]

19. Pan, Y.; Zhong, Z. A nonlinear constitutive model of unidirectional natural fiber reinforced composites considering moisture absorption. J. Mech. Phys. Solids 2014, 69, 132-142. [CrossRef]

20. Saheb, D.N.; Jog, J.P. Natural fiber polymer composites: A review. Adv. Polym. Technol. J. Polym. Process. Inst. 1999, 18, 351-363. [CrossRef]

21. Akil, H.M.; Cheng, L.W.; Ishak, Z.M.; Bakar, A.A.; Rahman, M.A. Water absorption study on pultruded jute fibre reinforced unsaturated polyester composites. Compos. Sci. Technol. 2009, 69, 1942-1948. [CrossRef]

22. Errajhi, O.; Osborne, J.; Richardson, M.; Dhakal, H. Water absorption characteristics of aluminised E-glass fibre reinforced unsaturated polyester composites. Compos. Struct. 2005, 71, 333-336. [CrossRef]

23. Banik, N.; Dey, V.; Sastry, G. An Overview of Lignin \& Hemicellulose Effect Upon Biodegradable Bamboo Fiber Composites Due to Moisture. Mater. Today Proc. 2017, 4, 3222-3232. [CrossRef]

24. Jauhari, N.; Mishra, R.; Thakur, H. Natural Fibre reinforced composite laminates-A review. Mater. Today Proc. 2015, 2, 2868-2877. [CrossRef] 
25. Gassan, J.; Bledzki, A.K. Effect of cyclic moisture absorption desorption on the mechanical properties of silanized jute-epoxy composites. Polym. Compos. 1999, 20, 604-611. [CrossRef]

26. Rassmann, S.; Reid, R.; Paskaramoorthy, R. Effects of processing conditions on the mechanical and water absorption properties of resin transfer moulded kenaf fibre reinforced polyester composite laminates. Compos. Part A Appl. Sci. Manuf. 2010, 41, 1612-1619. [CrossRef]

27. Tian, F.; Pan, Y.; Zhong, Z. A long-term mechanical degradation model of unidirectional natural fiber reinforced composites under hydrothermal ageing. Compos. Sci. Technol. 2017, 142, 156-162. [CrossRef]

28. Alomayri, T.; Assaedi, H.; Shaikh, F.; Low, I.M. Effect of water absorption on the mechanical properties of cotton fabric-reinforced geopolymer composites. J. Asian Ceram. Soc. 2014, 2, 223-230. [CrossRef]

29. El Messiry, M. Theoretical analysis of natural fiber volume fraction of reinforced composites. Alex. Eng. J. 2013, 52, 301-306. [CrossRef]

30. Mehra, N.; Mu, L.; Ji, T.; Li, Y.; Zhu, J. Moisture driven thermal conduction in polymer and polymer blends. Compos. Sci. Technol. 2017, 151, 115-123. [CrossRef]

31. De Albuquerque, A.; Joseph, K.; de Carvalho, L.H.; d'Almeida, J.R.M. Effect of wettability and ageing conditions on the physical and mechanical properties of uniaxially oriented jute-roving-reinforced polyester composites. Compos. Sci. Technol. 2000, 60, 833-844. [CrossRef]

32. Chevali, V.S.; Dean, D.R.; Janowski, G.M. Effect of environmental weathering on flexural creep behavior of long fiber-reinforced thermoplastic composites. Polym. Degrad. Stab. 2010, 95, 2628-2640. [CrossRef]

33. Toscano, A.; Pitarresi, G.; Scafidi, M.; Di Filippo, M.; Spadaro, G.; Alessi, S. Water diffusion and swelling stresses in highly crosslinked epoxy matrices. Polym. Degrad. Stab. 2016, 133, 255-263. [CrossRef]

34. Berthet, M.-A.; Gontard, N.; Angellier-Coussy, H. Impact of fibre moisture content on the structure/mechanical properties relationships of PHBV/wheat straw fibres biocomposites. Compos. Sci. Technol. 2015, 117, 386-391. [CrossRef]

35. Fang, Y.; Wang, K.; Hui, D.; Xu, F.; Liu, W.; Yang, S.; Wang, L. Monitoring of seawater immersion degradation in glass fibre reinforced polymer composites using quantum dots. Compos. Part B Eng. 2017, 112, 93-102. [CrossRef]

36. Hu, Y.; Li, X.; Lang, A.W.; Zhang, Y.; Nutt, S.R. Water immersion aging of polydicyclopentadiene resin and glass fiber composites. Polym. Degrad. Stab. 2016, 124, 35-42. [CrossRef]

37. Lai, M.; Botsis, J.; Cugnoni, J.; Coric, D. An experimental-numerical study of moisture absorption in an epoxy. Compos. Part A Appl. Sci. Manuf. 2012, 43, 1053-1060. [CrossRef]

38. Trache, D.; Hussin, M.H.; Chuin, C.T.H.; Sabar, S.; Fazita, M.N.; Taiwo, O.F.; Hassan, T.; Haafiz, M.M. Microcrystalline cellulose: Isolation, characterization and bio-composites application-A review. Int. J. Biol. Macromol. 2016, 93, 789-804. [CrossRef]

39. Humeau, C.; Davies, P.; Jacquemin, F. An experimental study of water diffusion in carbon/epoxy composites under static tensile stress. Compos. Part A Appl. Sci. Manuf. 2018, 107, 94-104. [CrossRef]

40. Shankar, G.; Kumar, S.K.; Mahato, P.K. Vibration analysis and control of smart composite plates with delamination and under hygrothermal environment. Thin-Walled Struct. 2017, 116, 53-68. [CrossRef]

41. Jiang, X.; Kolstein, H.; Bijlaard, F.S. Moisture diffusion in glass-fiber-reinforced polymer composite bridge under hot/wet environment. Compos. Part B Eng. 2013, 45, 407-416. [CrossRef]

42. Guermazi, N.; Tarjem, A.B.; Ksouri, I.; Ayedi, H.F. On the durability of FRP composites for aircraft structures in hygrothermal conditioning. Compos. Part B Eng. 2016, 85, 294-304. [CrossRef]

43. Biswal, M.; Sahu, S.; Asha, A. Vibration of composite cylindrical shallow shells subjected to hygrothermal loading-experimental and numerical results. Compos. Part B Eng. 2016, 98, 108-119. [CrossRef]

44. Mejri, M.; Toubal, L.; Cuillière, J.; François, V. Hygrothermal aging effects on mechanical and fatigue behaviors of a short-natural-fiber-reinforced composite. Int. J. Fatigue 2018, 108, 96-108. [CrossRef]

45. Furtado, S.C.; Araújo, A.L.; Silva, A. Inverse characterization of vegetable fibre-reinforced composites exposed to environmental degradation. Compos. Struct. 2018, 189, 529-544. [CrossRef]

46. Chow, C.; Xing, X.; Li, R. Moisture absorption studies of sisal fibre reinforced polypropylene composites. Compos. Sci. Technol. 2007, 67, 306-313. [CrossRef]

47. Alkbir, M.F.M.; Sapuan, S.M.; Nuraini, A.A.; Ishak, M.R. Fibre properties and crashworthiness parameters of natural fibre-reinforced composite structure: A literature review. Compos. Struct. 2016, 148, 59-73. [CrossRef]

48. Mittal, V.; Saini, R.; Sinha, S. Natural fiber-mediated epoxy composites-a review. Compos. Part B Eng. 2016, 99, 425-435. [CrossRef] 
49. Zamri, M.; Osman, M.; Akil, H.; Shahidan, M.; Ishak, Z.M. Development of green pultruded composites using kenaf fibre: Influence of linear mass density on weathering performance. J. Clean. Prod. 2016, 125, 320-330. [CrossRef]

50. Biagiotti, J.; Puglia, D.; Kenny, J.M. A review on natural fibre-based composites-part I: Structure, processing and properties of vegetable fibres. J. Nat. Fibers 2004, 1, 37-68. [CrossRef]

51. Wang, W.; Sain, M.; Cooper, P. Study of moisture absorption in natural fiber plastic composites. Compos. Sci. Technol. 2006, 66, 379-386. [CrossRef]

52. Doan, T.-T.-L.; Gao, S.-L.; Mäder, E. Jute/polypropylene composites I. Effect of matrix modification. Compos. Sci. Technol. 2006, 66, 952-963. [CrossRef]

53. Alexander, J.; Augustine, B.; Prudhuvi, S.; Paudel, A. Hygrothermal effect on natural frequency and damping characteristics of basalt/epoxy composites. Mater. Today Proc. 2016, 3, 1666-1671. [CrossRef]

54. Ho, M.-P.; Wang, H.; Lee, J.-H.; Ho, C.-K.; Lau, K.-T.; Leng, J.; Hui, D. Critical factors on manufacturing processes of natural fibre composites. Compos. Part B Eng. 2012, 43, 3549-3562. [CrossRef]

55. Pickering, K.L.; Efendy, M.A.; Le, T.M. A review of recent developments in natural fibre composites and their mechanical performance. Compos. Part A Appl. Sci. Manuf. 2016, 83, 98-112. [CrossRef]

56. Mokhothu, T.H.; John, M.J. Review on hygroscopic aging of cellulose fibres and their biocomposites. Carbohydr. Polym. 2015, 131, 337-354. [CrossRef] [PubMed]

57. Ramesh, M.; Palanikumar, K.; Reddy, K.H. Plant fibre based bio-composites: Sustainable and renewable green materials. Renew. Sustain. Energy Rev. 2017, 79, 558-584. [CrossRef]

58. Wang, W.; Sain, M.; Cooper, P. Hygrothermal weathering of rice hull/HDPE composites under extreme climatic conditions. Polym. Degrad. Stab. 2005, 90, 540-545. [CrossRef]

59. Xin, H.; Liu, Y.; Mosallam, A.; Zhang, Y. Moisture diffusion and hygrothermal aging of pultruded glass fiber reinforced polymer laminates in bridge application. Compos. Part B Eng. 2016, 100, 197-207. [CrossRef]

60. Dittenber, D.B.; GangaRao, H.V. Critical review of recent publications on use of natural composites in infrastructure. Compos. Part A Appl. Sci. Manuf. 2012, 43, 1419-1429. [CrossRef]

61. Jiang, X.; Kolstein, H.; Bijlaard, F.; Qiang, X. Effects of hygrothermal aging on glass-fibre reinforced polymer laminates and adhesive of FRP composite bridge: Moisture diffusion characteristics. Compos. Part A Appl. Sci. Manuf. 2014, 57, 49-58. [CrossRef]

62. Reddy, G.; Krishna, V.; Shanker, K. Tensile and Water Absorption Properties of FRP Composite Laminates without Voids and with Voids. Procedia Eng. 2017, 173, 1684-1691. [CrossRef]

63. Cheung, H.-Y.; Ho, M.-P.; Lau, K.-T.; Cardona, F.; Hui, D. Natural fibre-reinforced composites for bioengineering and environmental engineering applications. Compos. Part B Eng. 2009, 40, 655-663. [CrossRef]

64. Sanjay, M.; Madhu, P.; Jawaid, M.; Senthamaraikannan, P.; Senthil, S.; Pradeep, S. Characterization and properties of natural fiber polymer composites: A comprehensive review. J. Clean. Prod. 2018, 172, 566-581. [CrossRef]

65. Faruk, O.; Bledzki, A.K.; Fink, H.-P.; Sain, M. Biocomposites reinforced with natural fibers: 2000-2010. Prog. Polym. Sci. 2012, 37, 1552-1596. [CrossRef]

66. Regazzi, A.; Léger, R.; Corn, S.; Ienny, P. Modeling of hydrothermal aging of short flax fiber reinforced composites. Compos. Part A Appl. Sci. Manuf. 2016, 90, 559-566. [CrossRef]

67. Joseph, P.; Rabello, M.S.; Mattoso, L.; Joseph, K.; Thomas, S. Environmental effects on the degradation behaviour of sisal fibre reinforced polypropylene composites. Compos. Sci. Technol. 2002, 62, 1357-1372. [CrossRef]

68. Deo, C.; Acharya, S. Effect of moisture absorption on mechanical properties of chopped natural fiber reinforced epoxy composite. J. Reinf. Plast. Compos. 2010, 29, 2513-2521. [CrossRef]

69. Espert, A.; Vilaplana, F.; Karlsson, S. Comparison of water absorption in natural cellulosic fibres from wood and one-year crops in polypropylene composites and its influence on their mechanical properties. Compos. Part A Appl. Sci. Manuf. 2004, 35, 1267-1276. [CrossRef]

70. Sreekala, M.; Thomas, S. Effect of fibre surface modification on water-sorption characteristics of oil palm fibres. Compos. Sci. Technol. 2003, 63, 861-869. [CrossRef]

71. Miller, S.A.; Srubar, W.V.; Billington, S.L.; Lepech, M.D. Integrating durability-based service-life predictions with environmental impact assessments of natural fiber-reinforced composite materials. Resour. Conserv. Recycl. 2015, 99, 72-83. [CrossRef] 
72. Badji, C.; Beigbeder, J.; Garay, H.; Bergeret, A.; Bénézet, J.-C.; Desauziers, V. Correlation between artificial and natural weathering of hemp fibers reinforced polypropylene biocomposites. Polym. Degrad. Stab. 2018, 148, 117-131. [CrossRef]

73. Karthigeyan, P.; Raja, M.S.; Hariharan, R.; Karthikeyan, R.; Prakash, S. Performance evaluation of composite material for aircraft industries. Mater. Today Proc. 2017, 4, 3263-3269. [CrossRef]

74. Muktha, K.; Gowda, B.K. Investigation of Water Absorption and Fire Resistance of Untreated Banana Fibre Reinforced Polyester Composites. Mater. Today Proc. 2017, 4, 8307-8312. [CrossRef]

75. Pujari, S.; Ramakrishna, A.; Padal, K.B. Prediction of Swelling Behaviour of Jute and Banana Fiber Composites by using ANN and Regression Analysis. Mater. Today Proc. 2017, 4, 8548-8557. [CrossRef]

76. Leman, Z.; Sapuan, S.; Saifol, A.; Maleque, M.; Ahmad, M. Moisture absorption behavior of sugar palm fiber reinforced epoxy composites. Mater. Des. 2008, 29, 1666-1670. [CrossRef]

77. Yeh, S.-K.; Hsieh, C.-C.; Chang, H.-C.; Yen, C.C.; Chang, Y.-C. Synergistic effect of coupling agents and fiber treatments on mechanical properties and moisture absorption of polypropylene-rice husk composites and their foam. Compos. Part A Appl. Sci. Manuf. 2015, 68, 313-322. [CrossRef]

78. Ku, H.; Wang, H.; Pattarachaiyakoop, N.; Trada, M. A review on the tensile properties of natural fiber reinforced polymer composites. Compos. Part B Eng. 2011, 42, 856-873. [CrossRef]

79. Omrani, E.; Menezes, P.L.; Rohatgi, P.K. State of the art on tribological behavior of polymer matrix composites reinforced with natural fibers in the green materials world. Eng. Sci. Technol. Int. J. 2016, 19, 717-736. [CrossRef]

80. Mohanty, A.; Misra, M.; Drzal, L.T. Surface modifications of natural fibers and performance of the resulting biocomposites: An overview. Compos. Interfaces 2001, 8, 313-343. [CrossRef]

81. Sgriccia, N.; Hawley, M.; Misra, M. Characterization of natural fiber surfaces and natural fiber composites. Compos. Part A Appl. Sci. Manuf. 2008, 39, 1632-1637. [CrossRef]

82. Väisänen, T.; Batello, P.; Lappalainen, R.; Tomppo, L. Modification of hemp fibers (Cannabis Sativa L.) for composite applications. Ind. Crop. Prod. 2018, 111, 422-429. [CrossRef]

83. Liu, M.; Thygesen, A.; Summerscales, J.; Meyer, A.S. Targeted pre-treatment of hemp bast fibres for optimal performance in biocomposite materials: A review. Ind. Crop. Prod. 2017, 108, 660-683. [CrossRef]

84. Bledzki, A.K.; Mamun, A.A.; Jaszkiewicz, A.; Erdmann, K. Polypropylene composites with enzyme modified abaca fibre. Compos. Sci. Technol. 2010, 70, 854-860. [CrossRef]

85. Vilay, V.; Mariatti, M.; Taib, R.M.; Todo, M. Effect of fiber surface treatment and fiber loading on the properties of bagasse fiber-reinforced unsaturated polyester composites. Compos. Sci. Technol. 2008, 68, 631-638. [CrossRef]

86. Kushwaha, P.K.; Kumar, R. Studies on water absorption of bamboo-polyester composites: Effect of silane treatment of mercerized bamboo. Polym. Plast. Technol. Eng. 2009, 49, 45-52. [CrossRef]

87. Rout, J.; Misra, M.; Tripathy, S.; Nayak, S.; Mohanty, A. The influence of fibre treatment on the performance of coir-polyester composites. Compos. Sci. Technol. 2001, 61, 1303-1310. [CrossRef]

88. Fraga, A.; Frullloni, E.; De la Osa, O.; Kenny, J.; Vázquez, A. Relationship between water absorption and dielectric behaviour of natural fibre composite materials. Polym. Test. 2006, 25, 181-187. [CrossRef]

89. Croitoru, C.; Spirchez, C.; Lunguleasa, A.; Cristea, D.; Roata, I.C.; Pop, M.A.; Bedo, T.; Stanciu, E.M.; Pascu, A. Surface properties of thermally treated composite wood panels. Appl. Surf. Sci. 2018, 438, 114-126. [CrossRef]

90. Alvarez, V.A.; Vázquez, A. Influence of fiber chemical modification procedure on the mechanical properties and water absorption of MaterBi-Y/sisal fiber composites. Compos. Part A Appl. Sci. Manuf. 2006, 37, 1672-1680. [CrossRef]

91. Nirmal, U.; Hashim, J.; Ahmad, M.M. A review on tribological performance of natural fibre polymeric composites. Tribol. Int. 2015, 83, 77-104. [CrossRef]

92. Mohanty, A.; Khan, M.A.; Hinrichsen, G. Surface modification of jute and its influence on performance of biodegradable jute-fabric/Biopol composites. Compos. Sci. Technol. 2000, 60, 1115-1124. [CrossRef]

93. Al-Oqla, F.M.; Sapuan, S.; Anwer, T.; Jawaid, M.; Hoque, M. Natural fiber reinforced conductive polymer composites as functional materials: A review. Synth. Met. 2015, 206, 42-54. [CrossRef]

94. Fiore, V.; Scalici, T.; Nicoletti, F.; Vitale, G.; Prestipino, M.; Valenza, A. A new eco-friendly chemical treatment of natural fibres: Effect of sodium bicarbonate on properties of sisal fibre and its epoxy composites. Compos. Part B Eng. 2016, 85, 150-160. [CrossRef] 
95. Mwaikambo, L.; Ansell, M.P. The effect of chemical treatment on the properties of hemp, sisal, jute and kapok for composite reinforcement. Die Angew. Makromol. Chem. 1999, 272, 108-116. [CrossRef]

96. John, M.J.; Anandjiwala, R.D. Recent developments in chemical modification and characterization of natural fiber-reinforced composites. Polym. Compos. 2008, 29, 187-207. [CrossRef]

97. Hung, K.-C.; Chen, Y.-L.; Wu, J.-H. Natural weathering properties of acetylated bamboo plastic composites. Polym. Degrad. Stab. 2012, 97, 1680-1685. [CrossRef]

98. Kalia, S.; Kaith, B.; Kaur, I. Pretreatments of natural fibers and their application as reinforcing material in polymer composites-A review. Polym. Eng. Sci. 2009, 49, 1253-1272. [CrossRef]

99. Bogoeva-Gaceva, G.; Avella, M.; Malinconico, M.; Buzarovska, A.; Grozdanov, A.; Gentile, G.; Errico, M. Natural fiber eco-composites. Polym. Compos. 2007, 28, 98-107. [CrossRef]

100. Krishna, K.V.; Kanny, K. The effect of treatment on kenaf fiber using green approach and their reinforced epoxy composites. Compos. Part B Eng. 2016, 104, 111-117. [CrossRef]

101. Fernández, J.A.; Le Moigne, N.; Caro-Bretelle, A.; El Hage, R.; Le Duc, A.; Lozachmeur, M.; Bono, P.; Bergeret, A. Role of flax cell wall components on the microstructure and transverse mechanical behaviour of flax fabrics reinforced epoxy biocomposites. Ind. Crop. Prod. 2016, 85, 93-108. [CrossRef]

102. Alawar, A.; Hamed, A.M.; Al-Kaabi, K. Characterization of treated date palm tree fiber as composite reinforcement. Compos. Part B Eng. 2009, 40, 601-606. [CrossRef]

103. Shalwan, A.; Yousif, B. In state of art: Mechanical and tribological behaviour of polymeric composites based on natural fibres. Mater. Des. 2013, 48, 14-24. [CrossRef]

104. Singh, J.I.P.; Dhawan, V.; Singh, S.; Jangid, K. Study of Effect of Surface Treatment on Mechanical Properties of Natural Fiber Reinforced Composites. Mater. Today Proc. 2017, 4, 2793-2799. [CrossRef]

105. Sathishkumar, S.; Suresh, A.; Nagamadhu, M.; Krishna, M. The effect of alkaline treatment on their properties of Jute fiber mat and its vinyl ester composites. Mater. Today Proc. 2017, 4, 3371-3379. [CrossRef]

106. Punyamurthy, R.; Sampathkumar, D.; Srinivasa, C.V.; Bennehalli, B. Effect of alkali treatment on water absorption of single cellulosic abaca fiber. BioResources 2012, 7, 3515-3524.

107. Rao, K.M.M.; Rao, K.M.; Prasad, A.R. Fabrication and testing of natural fibre composites: Vakka, sisal, bamboo and banana. Mater. Des. 2010, 31, 508-513. [CrossRef]

108. Jayamani, E.; Hamdan, S.; Rahman, M.R.; Bakri, M.K.B. Investigation of fiber surface treatment on mechanical, acoustical and thermal properties of betelnut fiber polyester composites. Procedia Eng. 2014, 97, 545-554. [CrossRef]

109. Gopinath, A.; Kumar, M.S.; Elayaperumal, A. Experimental Investigations on Mechanical Properties Of Jute Fiber Reinforced Composites with Polyester and Epoxy Resin Matrices. Procedia Eng. 2014, 97, 2052-2063. [CrossRef]

110. Ridzuan, M.; Majid, M.A.; Afendi, M.; Kanafiah, S.A.; Zahri, J.; Gibson, A. Characterisation of natural cellulosic fibre from Pennisetum purpureum stem as potential reinforcement of polymer composites. Mater. Des. 2016, 89, 839-847. [CrossRef]

111. Le Troedec, M.; Sedan, D.; Peyratout, C.; Bonnet, J.P.; Smith, A.; Guinebretiere, R.; Gloaguen, V.; Krausz, P. Influence of various chemical treatments on the composition and structure of hemp fibres. Compos. Part $A$ Appl. Sci. Manuf. 2008, 39, 514-522. [CrossRef]

112. Yan, L.; Chouw, N.; Huang, L.; Kasal, B. Effect of alkali treatment on microstructure and mechanical properties of coir fibres, coir fibre reinforced-polymer composites and reinforced-cementitious composites. Constr. Build. Mater. 2016, 112, 168-182. [CrossRef]

113. Akhtar, M.N.; Sulong, A.B.; Radzi, M.F.; Ismail, N.; Raza, M.; Muhamad, N.; Khan, M.A. Influence of alkaline treatment and fiber loading on the physical and mechanical properties of kenaf/polypropylene composites for variety of applications. Prog. Nat. Sci. Mater. Int. 2016, 26, 657-664. [CrossRef]

114. Edeerozey, A.M.; Akil, H.M.; Azhar, A.; Ariffin, M.Z. Chemical modification of kenaf fibers. Mater. Lett. 2007, 61, 2023-2025. [CrossRef]

115. El-Abbassi, F.E.; Assarar, M.; Ayad, R.; Lamdouar, N. Effect of alkali treatment on Alfa fibre as reinforcement for polypropylene based eco-composites: Mechanical behaviour and water ageing. Compos. Struct. 2015, 133, 451-457. [CrossRef]

116. Hadjadj, A.; Jbara, O.; Tara, A.; Gilliot, M.; Malek, F.; Maafi, E.M.; Tighzert, L. Effects of cellulose fiber content on physical properties of polyurethane based composites. Compos. Struct. 2016, 135, 217-223. [CrossRef] 
117. Danjaji, I.; Nawang, R.; Ishiaku, U.; Ismail, H.; Ishak, Z.M. Degradation studies and moisture uptake of sago-starch-filled linear low-density polyethylene composites. Polym. Test. 2002, 21, 75-81. [CrossRef]

118. Mwaikambo, L.Y.; Ansell, M.P. Chemical modification of hemp, sisal, jute, and kapok fibers by alkalization. J. Appl. Polym. Sci. 2002, 84, 2222-2234. [CrossRef]

119. Sullins, T.; Pillay, S.; Komus, A.; Ning, H. Hemp fiber reinforced polypropylene composites: The effects of material treatments. Compos. Part B Eng. 2017, 114, 15-22. [CrossRef]

120. Abral, H.; Kadriadi, D.; Rodianus, A.; Mastariyanto, P.; Arief, S.; Sapuan, S.; Ishak, M.R. Mechanical properties of water hyacinth fibers-polyester composites before and after immersion in water. Mater. Des. 2014, 58, 125-129. [CrossRef]

121. Alvarez, V.A.; Ruscekaite, R.A.; Vazquez, A. Mechanical properties and water absorption behavior of composites made from a biodegradable matrix and alkaline-treated sisal fibers. J. Compos. Mater. 2003, 37, 1575-1588. [CrossRef]

122. Bakri, M.K.B.; Jayamani, E.; Hamdan, S. Processing and characterization of banana fiber/epoxy composites: Effect of alkaline treatment. Mater. Today Proc. 2017, 4, 2871-2878. [CrossRef]

123. JA, M.H.; Majid, M.A.; Afendi, M.; Marzuki, H.; Hilmi, E.A.; Fahmi, I.; Gibson, A. Effects of water absorption on Napier grass fibre/polyester composites. Compos. Struct. 2016, 144, 138-146. [CrossRef]

124. Sood, M.; Dwivedi, G. Effect of fiber treatment on flexural properties of natural fiber reinforced composites: A review. Egypt. J. Pet. 2018, 27, 775-783. [CrossRef]

125. Sepe, R.; Bollino, F.; Boccarusso, L.; Caputo, F. Influence of chemical treatments on mechanical properties of hemp fiber reinforced composites. Compos. Part B Eng. 2018, 133, 210-217. [CrossRef]

126. Naghmouchi, I.; Espinach, F.X.; Mutjé, P.; Boufi, S. Polypropylene composites based on lignocellulosic fillers: How the filler morphology affects the composite properties. Mater. Des. 2015, 65, 454-461. [CrossRef]

127. Bledzki, A.K.; Faruk, O. Creep and impact properties of wood fibre-polypropylene composites: Influence of temperature and moisture content. Compos. Sci. Technol. 2004, 64, 693-700. [CrossRef]

128. Xie, Y.; Hill, C.A.; Xiao, Z.; Militz, H.; Mai, C. Silane coupling agents used for natural fiber/polymer composites: A review. Compos. Part A Appl. Sci. Manuf. 2010, 41, 806-819. [CrossRef]

129. George, J.; Sreekala, M.; Thomas, S. A review on interface modification and characterization of natural fiber reinforced plastic composites. Polym. Eng. Sci. 2001, 41, 1471-1485. [CrossRef]

130. Li, X.; Tabil, L.G.; Panigrahi, S. Chemical treatments of natural fiber for use in natural fiber-reinforced composites: A review. J. Polym. Environ. 2007, 15, 25-33. [CrossRef]

131. Abdelmouleh, M.; Boufi, S.; Belgacem, M.N.; Dufresne, A. Short natural-fibre reinforced polyethylene and natural rubber composites: Effect of silane coupling agents and fibres loading. Compos. Sci. Technol. 2007, 67, 1627-1639. [CrossRef]

132. Zahari, W.; Badri, R.; Ardyananta, H.; Kurniawan, D.; Nor, F. Mechanical properties and water absorption behavior of polypropylene/ijuk fiber composite by using silane treatment. Procedia Manuf. 2015, 2, 573-578. [CrossRef]

133. Demir, H.; Atikler, U.; Balköse, D.; T1hmınlığlu, F. The effect of fiber surface treatments on the tensile and water sorption properties of polypropylene-luffa fiber composites. Compos. Part A Appl. Sci. Manuf. 2006, 37, 447-456. [CrossRef]

134. Thakur, V.K.; Thakur, M.K.; Gupta, R.K. Graft copolymers of natural fibers for green composites. Carbohydr. Polym. 2014, 104, 87-93. [CrossRef]

135. Arbelaiz, A.; Fernandez, B.; Ramos, J.; Retegi, A.; Llano-Ponte, R.; Mondragon, I. Mechanical properties of short flax fibre bundle/polypropylene composites: Influence of matrix/fibre modification, fibre content, water uptake and recycling. Compos. Sci. Technol. 2005, 65, 1582-1592. [CrossRef]

136. Rowell, R.M.; Sanadi, A.R.; Caulfield, D.F.; Jacobson, R.E. Utilization of Natural Fibers in Plastic Composites: Problems and Opportunities; Universidade de São Paulo: São Paulo, Brazil, 1997; pp. 23-51.

137. Lin, Q.; Zhou, X.; Dai, G. Effect of hydrothermal environment on moisture absorption and mechanical properties of wood flour-filled polypropylene composites. J. Appl. Polym. Sci. 2002, 85, 2824-2832. [CrossRef]

138. Karbhari, V.; Chin, J.; Hunston, D.; Benmokrane, B.; Juska, T.; Morgan, R.; Lesko, J.; Sorathia, U.; Reynaud, D. Durability gap analysis for fiber-reinforced polymer composites in civil infrastructure. J. Compos. Constr. 2003, 7, 238-247. [CrossRef]

139. Zhang, J.; Li, J.; Jin, X.; Du, S.; Kaur, J.; Wang, X. Natural and highly protective composite structures-Wild silkworm cocoons. Compos. Commun. 2017, 4, 1-4. [CrossRef] 
140. Hu, R.-H.; Sun, M.-Y.; Lim, J.-K. Moisture absorption, tensile strength and microstructure evolution of short jute fiber/polylactide composite in hygrothermal environment. Mater. Des. 2010, 31, 3167-3173. [CrossRef]

141. Liu, Z.; Tisserat, B.H. Coating applications to natural fiber composites to improve their physical, surface and water absorption characters. Ind. Crop. Prod. 2018, 112, 196-199. [CrossRef]

142. Wu, Y.; Xia, C.; Cai, L.; Shi, S.Q.; Cheng, J. Water-resistant hemp fiber-reinforced composites: In-situ surface protection by polyethylene film. Ind. Crop. Prod. 2018, 112, 210-216. [CrossRef]

143. Londhe, R.; Mache, A.; Kulkarni, A. An experimental study on moisture absorption for jute-epoxy composite with coatings exposed to different $\mathrm{pH}$ media. Perspect. Sci. 2016, 8, 580-582. [CrossRef]

144. Ooi, Z.X.; Ismail, H.; Bakar, A.A. Curing characteristics, mechanical, morphological, and swelling assessment of liquid epoxidized natural rubber coated oil palm ash reinforced natural rubber composites. Polym. Test. 2014, 33, 145-151. [CrossRef]

145. Bledzki, A.; Reihmane, S.; Gassan, J. Properties and modification methods for vegetable fibers for natural fiber composites. J. Appl. Polym. Sci. 1996, 59, 1329-1336. [CrossRef]

146. Bismarck, A.; Aranberri-Askargorta, I.; Springer, J.; Lampke, T.; Wielage, B.; Stamboulis, A.; Shenderovich, I.; Limbach, H.H. Surface characterization of flax, hemp and cellulose fibers; surface properties and the water uptake behavior. Polym. Compos. 2002, 23, 872-894. [CrossRef]

147. de Oliveira, D.M.; Cioffi, M.O.H.; de Carvalho Benini, K.C.C.; Voorwald, H.J.C. Effects of plasma treatment on the sorption properties of coconut fibers. Procedia Eng. 2017, 200, 357-364. [CrossRef]

148. De Velasco-Maldonado, P.S.; Hernández-Montoya, V.; Montes-Morán, M.A.; Vázquez, N.A.-R.; Pérez-Cruz, M.A. Surface modification of a natural zeolite by treatment with cold oxygen plasma: Characterization and application in water treatment. Appl. Surf. Sci. 2018, 434, 1193-1199. [CrossRef]

149. Cruz, J.; Fangueiro, R. Surface modification of natural fibers: A review. Procedia Eng. 2016, 155, $285-288$. [CrossRef]

150. Rao, J.; Bao, L.; Wang, B.; Fan, M.; Feo, L. Plasma surface modification and bonding enhancement for bamboo composites. Compos. Part B Eng. 2018, 138, 157-167. [CrossRef]

151. George, M.; Mussone, P.G.; Bressler, D.C. Surface and thermal characterization of natural fibres treated with enzymes. Ind. Crop. Prod. 2014, 53, 365-373. [CrossRef]

152. Yan, L.; Chouw, N.; Jayaraman, K. Flax fibre and its composites-A review. Compos. Part B Eng. 2014, 56, 296-317. [CrossRef]

153. Faruk, O.; Bledzki, A.K.; Fink, H.P.; Sain, M. Progress report on natural fiber reinforced composites. Macromol. Mater. Eng. 2014, 299, 9-26. [CrossRef]

154. Alamri, H.; Low, I.M. Mechanical properties and water absorption behaviour of recycled cellulose fibre reinforced epoxy composites. Polym. Test. 2012, 31, 620-628. [CrossRef]

155. Bahra, M.S.; Gupta, V.; Aggarwal, L. Effect of Fibre Content on Mechanical Properties and Water Absorption Behaviour of Pineapple/HDPE Composite. Mater. Today Proc. 2017, 4, 3207-3214. [CrossRef]

156. Dayo, A.Q.; Wang, A.-R.; Kiran, S.; Wang, J.; Qureshi, K.; Zegaoui, A.; Derradji, M.; Babar, A.A.; Liu, W.-B. Impacts of hemp fiber diameter on mechanical and water uptake properties of polybenzoxazine composites. Ind. Crop. Prod. 2018, 111, 277-284. [CrossRef]

157. Petchwattana, N.; Sanetuntikul, J.; Sriromreun, P.; Narupai, B. Wood plastic composites prepared from biodegradable poly (butylene succinate) and Burma Padauk sawdust (Pterocarpus macrocarpus): Water absorption kinetics and sunlight exposure investigations. J. Bionic Eng. 2017, 14, 781-790. [CrossRef]

158. Atiqah, A.; Jawaid, M.; Ishak, M.; Sapuan, S. Moisture absorption and thickness swelling behaviour of sugar palm fibre reinforced thermoplastic polyurethane. Procedia Eng. 2017, 184, 581-586. [CrossRef]

159. Masoodi, R.; Pillai, K.M. A study on moisture absorption and swelling in bio-based jute-epoxy composites. J. Reinf. Plast. Compos. 2012, 31, 285-294. [CrossRef]

160. Visco, A.; Campo, N.; Cianciafara, P. Comparison of seawater absorption properties of thermoset resins based composites. Compos. Part A Appl. Sci. Manuf. 2011, 42, 123-130. [CrossRef]

161. Kim, H.J.; Seo, D.W. Effect of water absorption fatigue on mechanical properties of sisal textile-reinforced composites. Int. J. Fatigue 2006, 28, 1307-1314. [CrossRef]

162. Christian, S.; Billington, S. Moisture diffusion and its impact on uniaxial tensile response of biobased composites. Compos. Part B Eng. 2012, 43, 2303-2312. [CrossRef]

163. Pan, Y.; Zhong, Z. A micromechanical model for the mechanical degradation of natural fiber reinforced composites induced by moisture absorption. Mech. Mater. 2015, 85, 7-15. [CrossRef] 
164. Varsavas, S.D.; Kaynak, C. Weathering degradation performance of PLA and its glass fiber reinforced composite. Mater. Today Commun. 2018, 15, 344-353. [CrossRef]

165. Puglia, D.; Biagiotti, J.; Kenny, J. A review on natural fibre-based composites-Part II: Application of natural reinforcements in composite materials for automotive industry. J. Nat. Fibers 2005, 1, 23-65. [CrossRef]

166. Yew, G.; Yusof, A.M.; Ishak, Z.M.; Ishiaku, U. Water absorption and enzymatic degradation of poly (lactic acid)/rice starch composites. Polym. Degrad. Stab. 2005, 90, 488-500. [CrossRef]

167. Do, V.-T.; Nguyen-Tran, H.-D.; Chun, D.-M. Effect of polypropylene on the mechanical properties and water absorption of carbon-fiber-reinforced-polyamide-6/polypropylene composite. Compos. Struct. 2016, 150, 240-245. [CrossRef]

168. Deng, H.; Reynolds, C.; Cabrera, N.; Barkoula, N.-M.; Alcock, B.; Peijs, T. The water absorption behaviour of all-polypropylene composites and its effect on mechanical properties. Compos. Part B Eng. 2010, 41, 268-275. [CrossRef]

169. Onuaguluchi, O.; Banthia, N. Plant-based natural fibre reinforced cement composites: A review. Cem. Concr. Compos. 2016, 68, 96-108. [CrossRef]

170. Castro, J.; Bentz, D.; Weiss, J. Effect of sample conditioning on the water absorption of concrete. Cem. Concr. Compos. 2011, 33, 805-813. [CrossRef]

171. Wei, J.; Meyer, C. Degradation mechanisms of natural fiber in the matrix of cement composites. Cem. Concr. Res. 2015, 73, 1-16. [CrossRef]

172. Wei, J.; Meyer, C. Degradation rate of natural fiber in cement composites exposed to various accelerated aging environment conditions. Corros. Sci. 2014, 88, 118-132. [CrossRef]

173. Claramunt, J.; Fernández-Carrasco, L.J.; Ventura, H.; Ardanuy, M. Natural fiber nonwoven reinforced cement composites as sustainable materials for building envelopes. Constr. Build. Mater. 2016, 115, 230-239. [CrossRef]

174. Li, H.; Xu, S.; Zeng, Q. Waterproof ultra-high toughness cementitious composites containing nano reservoir silts. Constr. Build. Mater. 2017, 155, 770-779. [CrossRef]

175. Ferreira, S.R.; de Andrade Silva, F.; Lima, P.R.L.; Toledo Filho, R.D. Effect of fiber treatments on the sisal fiber properties and fiber-matrix bond in cement based systems. Constr. Build. Mater. 2015, 101, 730-740. [CrossRef]

176. Ahmad, H.; Fan, M. Interfacial properties and structural performance of resin-coated natural fibre rebars within cementitious matrices. Cem. Concr. Compos. 2018, 87, 44-52. [CrossRef]

177. Fiore, V.; Scalici, T.; Di Bella, G.; Valenza, A. A review on basalt fibre and its composites. Compos. Part B Eng. 2015, 74, 74-94. [CrossRef]

178. Mitra, B.; Basak, R.; Sarkar, M. Studies on jute-reinforced composites, its limitations, and some solutions through chemical modifications of fibers. J. Appl. Polym. Sci. 1998, 67, 1093-1100. [CrossRef]

179. Zhang, D.; Milanovic, N.R.; Zhang, Y.; Su, F.; Miao, M. Effects of humidity conditions at fabrication on the interfacial shear strength of flax/unsaturated polyester composites. Compos. Part B Eng. 2014, 60, 186-192. [CrossRef]

180. Chen, H.; Miao, M.; Ding, X. Influence of moisture absorption on the interfacial strength of bamboo/vinyl ester composites. Compos. Part A Appl. Sci. Manuf. 2009, 40, 2013-2019. [CrossRef]

181. Koivuranta, E.; Hietala, M.; Ämmälä, A.; Oksman, K.; Illikainen, M. Improved durability of lignocellulose-polypropylene composites manufactured using twin-screw extrusion. Compos. Part A Appl. Sci. Manuf. 2017, 101, 265-272. [CrossRef]

182. Bajwa, D.S.; Bajwa, S.G.; Holt, G.A. Impact of biofibers and coupling agents on the weathering characteristics of composites. Polym. Degrad. Stab. 2015, 120, 212-219. [CrossRef]

183. Praveen, K.; Thomas, S.; Grohens, Y.; Mozetič, M.; Junkar, I.; Primc, G.; Gorjanc, M. Investigations of plasma induced effects on the surface properties of lignocellulosic natural coir fibres. Appl. Surf. Sci. 2016, 368, 146-156. [CrossRef]

184. Pejic, B.M.; Kostic, M.M.; Skundric, P.D.; Praskalo, J.Z. The effects of hemicelluloses and lignin removal on water uptake behavior of hemp fibers. Bioresour. Technol. 2008, 99, 7152-7159. [CrossRef]

185. Murariu, M.; Dubois, P. PLA composites: From production to properties. Adv. Drug Deliv. Rev. 2016, 107, 17-46. [CrossRef] 
186. Barari, B.; Omrani, E.; Moghadam, A.D.; Menezes, P.L.; Pillai, K.M.; Rohatgi, P.K. Mechanical, physical and tribological characterization of nano-cellulose fibers reinforced bio-epoxy composites: An attempt to fabricate and scale the 'Green'composite. Carbohydr. Polym. 2016, 147, 282-293. [CrossRef] [PubMed]

187. Ummartyotin, S.; Sain, M. Preparation of a cellulose and water-based resin composite. Mater. Lett. 2014, 123, 70-74. [CrossRef]

188. Srubar, W.V.; Miller, S.A.; Lepech, M.D.; Billington, S.L. Incorporating spatiotemporal effects and moisture diffusivity into a multi-criteria materials selection methodology for wood-polymer composites. Constr. Build. Mater. 2014, 71, 589-601. [CrossRef]

189. Mrad, H.; Alix, S.; Migneault, S.; Koubaa, A.; Perré, P. Numerical and experimental assessment of water absorption of wood-polymer composites. Measurement 2018, 115, 197-203. [CrossRef]

190. Kaboorani, A. Characterizing water sorption and diffusion properties of wood/plastic composites as a function of formulation design. Constr. Build. Mater. 2017, 136, 164-172. [CrossRef]

191. Tamrakar, S.; Lopez-Anido, R.A. Water absorption of wood polypropylene composite sheet piles and its influence on mechanical properties. Constr. Build. Mater. 2011, 25, 3977-3988. [CrossRef]

192. Homkhiew, C.; Ratanawilai, T.; Thongruang, W. Effects of natural weathering on the properties of recycled polypropylene composites reinforced with rubberwood flour. Ind. Crop. Prod. 2014, 56, 52-59. [CrossRef]

193. Machado, J.S.; Santos, S.; Pinho, F.F.; Luís, F.; Alves, A.; Simões, R.; Rodrigues, J.C. Impact of high moisture conditions on the serviceability performance of wood plastic composite decks. Mater. Des. 2016, 103, $122-131$. [CrossRef]

194. Schirp, A.; Wolcott, M.P. Influence of fungal decay and moisture absorption on mechanical properties of extruded wood-plastic composites. Wood Fiber Sci. 2007, 37, 643-652.

195. Fakhrul, T.; Islam, M. Degradation behavior of natural fiber reinforced polymer matrix composites. Procedia Eng. 2013, 56, 795-800. [CrossRef]

196. Qing, Y.; Liu, M.; Wu, Y.; Jia, S.; Wang, S.; Li, X. Investigation on stability and moisture absorption of superhydrophobic wood under alternating humidity and temperature conditions. Results Phys. 2017, 7, 1705-1711. [CrossRef]

197. Hosseinaei, O.; Wang, S.; Taylor, A.M.; Kim, J.-W. Effect of hemicellulose extraction on water absorption and mold susceptibility of wood-plastic composites. Int. Biodeterior. Biodegrad. 2012, 71, 29-35. [CrossRef]

198. Adhikary, K.B.; Pang, S.; Staiger, M.P. Long-term moisture absorption and thickness swelling behaviour of recycled thermoplastics reinforced with Pinus radiata sawdust. Chem. Eng. J. 2008, 142, 190-198. [CrossRef]

199. Bessa, J.; Mota, C.; Cunha, F.; Fangueiro, R. Influence of different thermoplastic polymer/wood ratios on the mechanical and thermal properties of composite materials. Procedia Eng. 2017, 200, 480-486. [CrossRef]

200. Yeh, S.-K.; Gupta, R.K. Improved wood-plastic composites through better processing. Compos. Part A Appl. Sci. Manuf. 2008, 39, 1694-1699. [CrossRef]

201. Beg, M.D.H.; Pickering, K.L. Reprocessing of wood fibre reinforced polypropylene composites. Part II: Hygrothermal ageing and its effects. Compos. Part A Appl. Sci. Manuf. 2008, 39, 1565-1571. [CrossRef]

202. Butylina, S.; Hyvärinen, M.; Kärki, T. A study of surface changes of wood-polypropylene composites as the result of exterior weathering. Polym. Degrad. Stab. 2012, 97, 337-345. [CrossRef]

203. Saidane, E.H.; Scida, D.; Assarar, M.; Ayad, R. Assessment of 3D moisture diffusion parameters on flax/epoxy composites. Compos. Part A Appl. Sci. Manuf. 2016, 80, 53-60. [CrossRef]

204. Fuentes, C.; Ting, K.; Dupont-Gillain, C.; Steensma, M.; Talma, A.; Zuijderduin, R.; Van Vuure, A. Effect of humidity during manufacturing on the interfacial strength of non-pre-dried flax fibre/unsaturated polyester composites. Compos. Part A Appl. Sci. Manuf. 2016, 84, 209-215. [CrossRef]

205. Le Duigou, A.; Castro, M. Moisture-induced self-shaping flax-reinforced polypropylene biocomposite actuator. Ind. Crop. Prod. 2015, 71, 1-6. [CrossRef]

206. Le Duigou, A.; Bourmaud, A.; Davies, P.; Baley, C. Long term immersion in natural seawater of Flax/PLA biocomposite. Ocean Eng. 2014, 90, 140-148. [CrossRef]

207. Chilali, A.; Zouari, W.; Assarar, M.; Kebir, H.; Ayad, R. Effect of water ageing on the load-unload cyclic behaviour of flax fibre-reinforced thermoplastic and thermosetting composites. Compos. Struct. 2018, 183, 309-319. [CrossRef]

208. Masseteau, B.; Michaud, F.; Irle, M.; Roy, A.; Alise, G. An evaluation of the effects of moisture content on the modulus of elasticity of a unidirectional flax fiber composite. Compos. Part A Appl. Sci. Manuf. 2014, 60, 32-37. [CrossRef] 
209. Berges, M.; Léger, R.; Placet, V.; Person, V.; Corn, S.; Gabrion, X.; Rousseau, J.; Ramasso, E.; Ienny, P.; Fontaine, S. Influence of moisture uptake on the static, cyclic and dynamic behaviour of unidirectional flax fibre-reinforced epoxy laminates. Compos. Part A Appl. Sci. Manuf. 2016, 88, 165-177. [CrossRef]

210. Saidane, E.H.; Scida, D.; Assarar, M.; Sabhi, H.; Ayad, R. Hybridisation effect on diffusion kinetic and tensile mechanical behaviour of epoxy based flax-glass composites. Compos. Part A Appl. Sci. Manuf. 2016, 87, 153-160. [CrossRef]

211. Pucci, M.F.; Liotier, P.-J.; Drapier, S. Capillary wicking in flax fabrics-effects of swelling in water. Colloids Surf. A Physicochem. Eng. Asp. 2016, 498, 176-184. [CrossRef]

212. Bulota, M.; Budtova, T. Highly porous and light-weight flax/PLA composites. Ind. Crop. Prod. 2015, 74, 132-138. [CrossRef]

213. Chilali, A.; Assarar, M.; Zouari, W.; Kebir, H.; Ayad, R. Effect of geometric dimensions and fibre orientation on 3D moisture diffusion in flax fibre reinforced thermoplastic and thermosetting composites. Compos. Part A Appl. Sci. Manuf. 2017, 95, 75-86. [CrossRef]

214. Stamboulis, A.; Baillie, C.; Garkhail, S.; Van Melick, H.; Peijs, T. Environmental durability of flax fibres and their composites based on polypropylene matrix. Appl. Compos. Mater. 2000, 7, 273-294. [CrossRef]

215. Wang, B.; Panigrahi, S.; Tabil, L.; Crerar, W. Pre-treatment of flax fibers for use in rotationally molded biocomposites. J. Reinf. Plast. Compos. 2007, 26, 447-463. [CrossRef]

216. Georgiopoulos, P.; Christopoulos, A.; Koutsoumpis, S.; Kontou, E. The effect of surface treatment on the performance of flax/biodegradable composites. Compos. Part B Eng. 2016, 106, 88-98. [CrossRef]

217. Cuinat-Guerraz, N.; Dumont, M.-J.; Hubert, P. Environmental resistance of flax/bio-based epoxy and flax/polyurethane composites manufactured by resin transfer moulding. Compos. Part A Appl. Sci. Manuf. 2016, 88, 140-147. [CrossRef]

218. Baghaei, B.; Skrifvars, M.; Salehi, M.; Bashir, T.; Rissanen, M.; Nousiainen, P. Novel aligned hemp fibre reinforcement for structural biocomposites: Porosity, water absorption, mechanical performances and viscoelastic behaviour. Compos. Part A Appl. Sci. Manuf. 2014, 61,1-12. [CrossRef]

219. Baghaei, B.; Skrifvars, M.; Berglin, L. Characterization of thermoplastic natural fibre composites made from woven hybrid yarn prepregs with different weave pattern. Compos. Part A Appl. Sci. Manuf. 2015, 76, 154-161. [CrossRef]

220. Sair, S.; Oushabi, A.; Kammouni, A.; Tanane, O.; Abboud, Y.; Hassani, F.O.; Laachachi, A.; El Bouari, A. Effect of surface modification on morphological, mechanical and thermal conductivity of hemp fiber: Characterization of the interface of hemp-Polyurethane composite. Case Stud. Therm. Eng. 2017, 10, 550-559. [CrossRef]

221. Haghighatnia, T.; Abbasian, A.; Morshedian, J. Hemp fiber reinforced thermoplastic polyurethane composite: An investigation in mechanical properties. Ind. Crop. Prod. 2017, 108, 853-863. [CrossRef]

222. Dayo, A.Q.; Gao, B.-C.; Wang, J.; Liu, W.-B.; Derradji, M.; Shah, A.H.; Babar, A.A. Natural hemp fiber reinforced polybenzoxazine composites: Curing behavior, mechanical and thermal properties. Compos. Sci. Technol. 2017, 144, 114-124. [CrossRef]

223. Balčiūnas, G.; Žvironaitè, J.; Vejelis, S.; Jagniatinskis, A.; Gaidučis, S. Ecological, thermal and acoustical insulating composite from hemp shives and sapropel binder. Ind. Crop. Prod. 2016, 91, 286-294. [CrossRef]

224. Rouison, D.; Couturier, M.; Sain, M.; MacMillan, B.; Balcom, B. Water absorption of hemp fiber/unsaturated polyester composites. Polym. Compos. 2005, 26, 509-525. [CrossRef]

225. Dhakal, H.; Zhang, Z.; Richardson, M. Effect of water absorption on the mechanical properties of hemp fibre reinforced unsaturated polyester composites. Compos. Sci. Technol. 2007, 67, 1674-1683. [CrossRef]

226. Perrier, A.; Le Bourhis, E.; Touchard, F.; Chocinski-Arnault, L. Effect of water ageing on nanoindentation response of single hemp yarn/epoxy composites. Compos. Part A Appl. Sci. Manuf. 2016, 84, 216-223. [CrossRef]

227. Fotouh, A.; Wolodko, J.D.; Lipsett, M.G. Fatigue of natural fiber thermoplastic composites. Compos. Part B Eng. 2014, 62, 175-182. [CrossRef]

228. Perrier, A.; Touchard, F.; Chocinski-Arnault, L.; Mellier, D. Influence of water on damage and mechanical behaviour of single hemp yarn composites. Polym. Test. 2017, 57, 17-25. [CrossRef]

229. Väisänen, T.; Das, O.; Tomppo, L. A review on new bio-based constituents for natural fiber-polymer composites. J. Clean. Prod. 2017, 149, 582-596. [CrossRef] 
230. Gunning, M.A.; Geever, L.M.; Killion, J.A.; Lyons, J.G.; Higginbotham, C.L. Mechanical and biodegradation performance of short natural fibre polyhydroxybutyrate composites. Polym. Test. 2013, 32, 1603-1611. [CrossRef]

231. Pan, Y.; Zhong, Z. Modeling of the mechanical degradation induced by moisture absorption in short natural fiber reinforced composites. Compos. Sci. Technol. 2014, 103, 22-27. [CrossRef]

232. Kejariwal, R.K.; Gowda, B.K. Flammability and moisture absorption behavior of sisal-polyester composites. Mater. Today Proc. 2017, 4, 8040-8044. [CrossRef]

233. Das, S. Mechanical and water swelling properties of waste paper reinforced unsaturated polyester composites. Constr. Build. Mater. 2017, 138, 469-478. [CrossRef]

234. Sanjay, M.; Yogesha, B. Studies on natural/glass fiber reinforced polymer hybrid composites: An evolution. Mater. Today Proc. 2017, 4, 2739-2747. [CrossRef]

235. Venkateshwaran, N.; ElayaPerumal, A.; Alavudeen, A.; Thiruchitrambalam, M. Mechanical and water absorption behaviour of banana/sisal reinforced hybrid composites. Mater. Des. 2011, 32, 4017-4021. [CrossRef]

236. Zamri, M.H.; Akil, H.M.; Bakar, A.A.; Ishak, Z.A.M.; Cheng, L.W. Effect of water absorption on pultruded jute/glass fiber-reinforced unsaturated polyester hybrid composites. J. Compos. Mater. 2012, 46, 51-61. [CrossRef]

237. Panthapulakkal, S.; Sain, M. Injection-molded short hemp fiber/glass fiber-reinforced polypropylene hybrid composites-Mechanical, water absorption and thermal properties. J. Appl. Polym. Sci. 2007, 103, 2432-2441. [CrossRef]

238. Gupta, M.; Srivastava, R. Effect of sisal fibre loading on dynamic mechanical analysis and water absorption behaviour of jute fibre epoxy composite. Mater. Today Proc. 2015, 2, 2909-2917. [CrossRef]

239. Bansal, S.; Ramachandran, M.; Raichurkar, P. Comparative Analysis of Bamboo using Jute and Coir Fiber Reinforced Polymeric Composites. Mater. Today Proc. 2017, 4, 3182-3187. [CrossRef]

240. Chandramohan, D.; Kumar, A.J.P. Experimental data on the properties of natural fiber particle reinforced polymer composite material. Data Brief 2017, 13, 460-468. [CrossRef]

241. Collet, F.; Prétot, S.; Lanos, C. Hemp-Straw Composites: Thermal And Hygric Performances. Energy Procedia 2017, 139, 294-300. [CrossRef]

242. Arunkumar, D.; Gupta, N.V.; Rao, K.S. Effect of Samanea Saman Pod Pulp on Mechanical and Water Absorption Properties of Bio-Composites. Mater. Today Proc. 2017, 4, 9592-9596. [CrossRef]

243. Almansour, F.; Dhakal, H.; Zhang, Z.Y. Effect of water absorption on Mode I interlaminar fracture toughness of flax/basalt reinforced vinyl ester hybrid composites. Compos. Struct. 2017, 168, 813-825. [CrossRef]

244. Živković, I.; Fragassa, C.; Pavlović, A.; Brugo, T. Influence of moisture absorption on the impact properties of flax, basalt and hybrid flax/basalt fiber reinforced green composites. Compos. Part B Eng. 2017, 111, 148-164. [CrossRef]

245. Sature, P.; Mache, A. Experimental and numerical study on moisture diffusion phenomenon of natural fiber based composites. Mater. Today Proc. 2017, 4, 10293-10297. [CrossRef]

246. Sarasini, F.; Tirillò, J.; Sergi, C.; Seghini, M.C.; Cozzarini, L.; Graupner, N. Effect of basalt fibre hybridisation and sizing removal on mechanical and thermal properties of hemp fibre reinforced HDPE composites. Compos. Struct. 2018, 188, 394-406. [CrossRef]

247. Fiore, V.; Scalici, T.; Calabrese, L.; Valenza, A.; Proverbio, E. Effect of external basalt layers on durability behaviour of flax reinforced composites. Compos. Part B Eng. 2016, 84, 258-265. [CrossRef]

248. Maslinda, A.; Majid, M.A.; Ridzuan, M.; Afendi, M.; Gibson, A. Effect of water absorption on the mechanical properties of hybrid interwoven cellulosic-cellulosic fibre reinforced epoxy composites. Compos. Struct. 2017, 167, 227-237. [CrossRef]

249. Rouison, D.; Sain, M.; Couturier, M. Resin transfer molding of natural fiber reinforced composites: Cure simulation. Compos. Sci. Technol. 2004, 64, 629-644. [CrossRef]

250. Athijayamani, A.; Thiruchitrambalam, M.; Natarajan, U.; Pazhanivel, B. Effect of moisture absorption on the mechanical properties of randomly oriented natural fibers/polyester hybrid composite. Mater. Sci. Eng. A 2009, 517, 344-353. [CrossRef]

251. Ashori, A.; Sheshmani, S. Hybrid composites made from recycled materials: Moisture absorption and thickness swelling behavior. Bioresour. Technol. 2010, 101, 4717-4720. [CrossRef] [PubMed] 
252. Flynn, J.; Amiri, A.; Ulven, C. Hybridized carbon and flax fiber composites for tailored performance. Mater. Des. 2016, 102, 21-29. [CrossRef]

253. Ramana, M.V.; Ramprasad, S. Experimental investigation on jute/carbon fibre reinforced epoxy based hybrid composites. Mater. Today Proc. 2017, 4, 8654-8664. [CrossRef]

254. Kanitkar, Y.M.; Kulkarni, A.P.; Wangikar, K.S. Characterization of glass hybrid composite: A review. Mater. Today Proc. 2017, 4, 9627-9630. [CrossRef]

255. Dhakal, H.; Zhang, Z.; Guthrie, R.; MacMullen, J.; Bennett, N. Development of flax/carbon fibre hybrid composites for enhanced properties. Carbohydr. Polym. 2013, 96, 1-8. [CrossRef] [PubMed]

256. Valluzzi, M.R.; Nardon, F.; Garbin, E.; Panizza, M. Multi-scale characterization of moisture and thermal cycle effects on composite-to-timber strengthening. Constr. Build. Mater. 2016, 102, 1070-1083. [CrossRef]

257. Kumar, G.H.; Babuvishwanath, H.; Purohit, R.; Sahu, P.; Rana, R. Investigations On Mechanical Properties Of Glass And Sugarcane Fiber Polymer Matrix Composites. Mater. Today Proc. 2017, 4, 5408-5420. [CrossRef]

258. Sanjay, M.; Arpitha, G.; Yogesha, B. Study on mechanical properties of natural-glass fibre reinforced polymer hybrid composites: A review. Mater. Today Proc. 2015, 2, 2959-2967. [CrossRef]

259. Otto, G.P.; Moisés, M.P.; Carvalho, G.; Rinaldi, A.W.; Garcia, J.C.; Radovanovic, E.; Fávaro, S.L. Mechanical properties of a polyurethane hybrid composite with natural lignocellulosic fibers. Compos. Part B Eng. 2017, 110, 459-465. [CrossRef]

260. Omrani, F.; Wang, P.; Soulat, D.; Ferreira, M. Mechanical properties of flax-fibre-reinforced preforms and composites: Influence of the type of yarns on multi-scale characterisations. Compos. Part A Appl. Sci. Manuf. 2017, 93, 72-81. [CrossRef]

261. Kumar, S.; Gangil, B.; Prasad, L.; Patel, V.K. A Review on Mechanical Behaviour of Bast-Glass Fibre Based Hybrid Polymer Composites. Mater. Today Proc. 2017, 4, 9576-9580. [CrossRef]

262. Hristozov, D.; Wroblewski, L.; Sadeghian, P. Long-term tensile properties of natural fibre-reinforced polymer composites: Comparison of flax and glass fibres. Compos. Part B Eng. 2016, 95, 82-95. [CrossRef]

263. Pan, Y.; Zhong, Z. The effect of hybridization on moisture absorption and mechanical degradation of natural fiber composites: An analytical approach. Compos. Sci. Technol. 2015, 110, 132-137. [CrossRef]

264. Westman, M.P.; Fifield, L.S.; Simmons, K.L.; Laddha, S.; Kafentzis, T.A. Natural Fiber Composites: A Review; Pacific Northwest National Laboratory: Richland, WA, USA, 2010.

265. Manteghi, S.; Mahboob, Z.; Fawaz, Z.; Bougherara, H. Investigation of the mechanical properties and failure modes of hybrid natural fiber composites for potential bone fracture fixation plates. J. Mech. Behav. Biomed. Mater. 2017, 65, 306-316. [CrossRef]

266. Yu, H.; Zhou, C. Sandwich diffusion model for moisture absorption of flax/glass fiber reinforced hybrid composite. Compos. Struct. 2018, 188, 1-6. [CrossRef]

267. Ridzuan, M.; Majid, M.A.; Afendi, M.; Azduwin, K.; Amin, N.; Zahri, J.; Gibson, A. Moisture absorption and mechanical degradation of hybrid Pennisetum purpureum/glass-epoxy composites. Compos. Struct. 2016, 141, 110-116. [CrossRef]

268. Sanadi, A.R.; Calufield, D.; Rowell, R.M. Reinforcing polypropylene with natural fibers. Plast. Eng. (USA) 1994, 50, 27-28.

269. Chaichanawong, J.; Thongchuea, C.; Areerat, S. Effect of moisture on the mechanical properties of glass fiber reinforced polyamide composites. Adv. Powder Technol. 2016, 27, 898-902. [CrossRef]

270. Wambua, P.; Ivens, J.; Verpoest, I. Natural fibres: Can they replace glass in fibre reinforced plastics? Compos. Sci. Technol. 2003, 63, 1259-1264. [CrossRef]

271. Assarar, M.; Scida, D.; El Mahi, A.; Poilâne, C.; Ayad, R. Influence of water ageing on mechanical properties and damage events of two reinforced composite materials: Flax-fibres and glass-fibres. Mater. Des. 2011, 32, 788-795. [CrossRef]

272. Aquino, E.; Sarmento, L.; Oliveira, W.; Silva, R. Moisture effect on degradation of jute/glass hybrid composites. J. Reinf. Plast. Compos. 2007, 26, 219-233. [CrossRef]

273. Hassanin, A.H.; Hamouda, T.; Candan, Z.; Kilic, A.; Akbulut, T. Developing high-performance hybrid green composites. Compos. Part B Eng. 2016, 92, 384-394. [CrossRef]

274. Thwe, M.M.; Liao, K. Durability of bamboo-glass fiber reinforced polymer matrix hybrid composites. Compos. Sci. Technol. 2003, 63, 375-387. [CrossRef]

275. Thwe, M.M.; Liao, K. Effects of environmental aging on the mechanical properties of bamboo-glass fiber reinforced polymer matrix hybrid composites. Compos. Part A Appl. Sci. Manuf. 2002, 33, 43-52. [CrossRef] 
276. Akil, H.M.; Santulli, C.; Sarasini, F.; Tirillò, J.; Valente, T. Environmental effects on the mechanical behaviour of pultruded jute/glass fibre-reinforced polyester hybrid composites. Compos. Sci. Technol. 2014, 94, 62-70. [CrossRef]

277. Salleh, Z.; Taib, Y.; Hyie, K.M.; Mihat, M.; Berhan, M.; Ghani, M. Fracture toughness investigation on long kenaf/woven glass hybrid composite due to water absorption effect. Procedia Eng. 2012, 41, 1667-1673. [CrossRef]

278. Saidane, E.H.; Scida, D.; Assarar, M.; Ayad, R. Damage mechanisms assessment of hybrid flax-glass fibre composites using acoustic emission. Compos. Struct. 2017, 174, 1-11. [CrossRef]

279. Ghani, M.; Salleh, Z.; Hyie, K.M.; Berhan, M.; Taib, Y.; Bakri, M. Mechanical properties of kenaf/fiberglass polyester hybrid composite. Procedia Eng. 2012, 41, 1654-1659. [CrossRef]

280. Anbukarasi, K.; Kalaiselvam, S. Study of effect of fibre volume and dimension on mechanical, thermal, and water absorption behaviour of luffa reinforced epoxy composites. Mater. Des. 2015, 66, 321-330. [CrossRef]

281. Amran, U.A.; Zakaria, S.; Chia, C.H.; Jaafar, S.N.S.; Roslan, R. Mechanical properties and water absorption of glass fibre reinforced bio-phenolic elastomer (BPE) composite. Ind. Crop. Prod. 2015, 72, 54-59. [CrossRef]

282. Shubhra, Q.T.; Alam, A.; Khan, M.A.; Saha, M.; Saha, D.; Gafur, M. Study on the mechanical properties, environmental effect, degradation characteristics and ionizing radiation effect on silk reinforced polypropylene/natural rubber composites. Compos. Part A Appl. Sci. Manuf. 2010, 41, 1587-1596. [CrossRef]

283. Liu, H.; Liu, C.; Peng, S.; Pan, B.; Lu, C. Effect of polyethyleneimine modified graphene on the mechanical and water vapor barrier properties of methyl cellulose composite films. Carbohydr. Polym. 2018, 182, 52-60. [CrossRef] [PubMed]

284. Pappu, A.; Thakur, V.K. Towards sustainable micro and nano composites from fly ash and natural fibers for multifunctional applications. Vacuum 2017, 146, 375-385. [CrossRef]

285. Adhikari, J.; Biswas, B.; Chabri, S.; Bandyapadhyay, N.R.; Sawai, P.; Mitra, B.C.; Sinha, A. Effect of functionalized metal oxides addition on the mechanical, thermal and swelling behaviour of polyester/jute composites. Eng. Sci. Technol. Int. J. 2017, 20, 760-774. [CrossRef]

286. Xia, C.; Wang, K.; Dong, Y.; Zhang, S.; Shi, S.Q.; Cai, L.; Ren, H.; Zhang, H.; Li, J. Dual-functional natural-fiber reinforced composites by incorporating magnetite. Compos. Part B Eng. 2016, 93, 221-228. [CrossRef]

287. Nayak, R.K.; Mahato, K.K.; Ray, B.C. Water absorption behavior, mechanical and thermal properties of nano $\mathrm{TiO}_{2}$ enhanced glass fiber reinforced polymer composites. Compos. Part A Appl. Sci. Manuf. 2016, 90, 736-747. [CrossRef]

288. Foruzanmehr, M.; Vuillaume, P.Y.; Elkoun, S.; Robert, M. Physical and mechanical properties of PLA composites reinforced by TiO2 grafted flax fibers. Mater. Des. 2016, 106, 295-304. [CrossRef]

289. Yang, B.; Zhang, J.; Zhou, L.; Lu, M.; Liang, W.; Wang, Z. Effect of fiber surface modification on water absorption and hydrothermal aging behaviors of GF/pCBT composites. Compos. Part B Eng. 2015, 82, 84-91. [CrossRef]

290. Kord, B.; Roohani, M. Water transport kinetics and thickness swelling behavior of natural fiber-reinforced HDPE/CNT nanocomposites. Compos. Part B Eng. 2017, 126, 94-99. [CrossRef]

291. Kim, M.T.; Rhee, K.Y.; Jung, I.; Park, S.J.; Hui, D. Influence of seawater absorption on the vibration damping characteristics and fracture behaviors of basalt/CNT/epoxy multiscale composites. Compos. Part B: Eng. 2014, 63, 61-66. [CrossRef]

292. Morán, J.I.; Alvarez, V.A.; Cyras, V.P.; Vázquez, A. Extraction of cellulose and preparation of nanocellulose from sisal fibers. Cellulose 2008, 15, 149-159. [CrossRef]

293. Popescu, M.-C.; Dogaru, B.-I.; Popescu, C.-M. The influence of cellulose nanocrystals content on the water sorption properties of bio-based composite films. Mater. Des. 2017, 132, 170-177. [CrossRef]

294. Wan, Y.; Luo, H.; He, F.; Liang, H.; Huang, Y.; Li, X. Mechanical, moisture absorption, and biodegradation behaviours of bacterial cellulose fibre-reinforced starch biocomposites. Compos. Sci. Technol. 2009, 69, 1212-1217. [CrossRef]

295. Debnath, S.; Nguong, C.; Lee, S. A review on natural fibre reinforced polymer composites. World Acad. Sci. Eng. Technol. 2013, 7, 1123-1130.

296. Sharma, B.; Chhibber, R.; Mehta, R. Seawater ageing of glass fiber reinforced epoxy nanocomposites based on silylated clays. Polym. Degrad. Stab. 2018, 147, 103-114. [CrossRef] 
297. Mittal, G.; Dhand, V.; Rhee, K.Y.; Park, S.J.; Kim, H.-J.; Jung, D.H. Investigation of seawater effects on the mechanical properties of untreated and treated MMT-based glass fiber/vinylester composites. Ocean Eng. 2015, 108, 393-401. [CrossRef]

298. Hossain, M.K.; Chowdhury, M.M.R.; Imran, K.A.; Salam, M.B.; Tauhid, A.; Hosur, M.; Jeelani, S. Effect of low velocity impact responses on durability of conventional and nanophased CFRP composites exposed to seawater. Polym. Degrad. Stab. 2014, 99, 180-189. [CrossRef]

299. Madyan, O.A.; Fan, M.; Huang, Z. Functional clay aerogel composites through hydrophobic modification and architecture of layered clays. Appl. Clay Sci. 2017, 141, 64-71. [CrossRef]

(C) 2019 by the authors. Licensee MDPI, Basel, Switzerland. This article is an open access article distributed under the terms and conditions of the Creative Commons Attribution (CC BY) license (http://creativecommons.org/licenses/by/4.0/). 